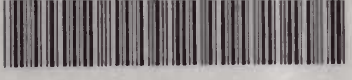

В 3 ᄅ? $\quad 115$

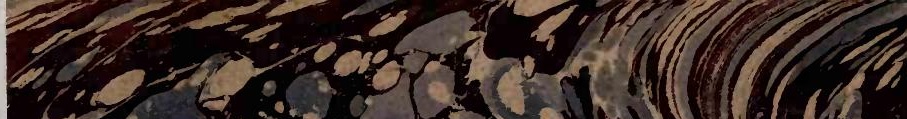

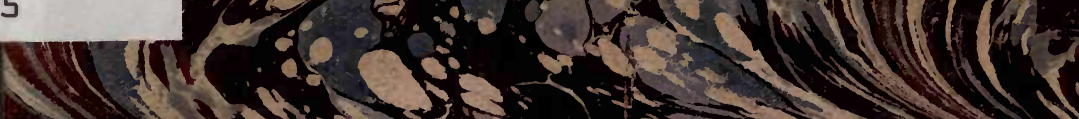

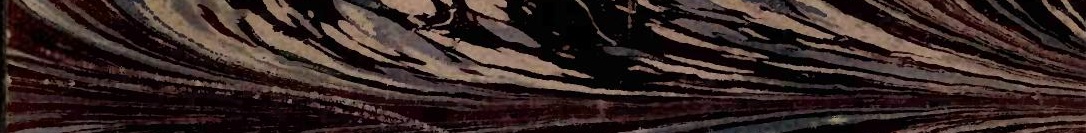

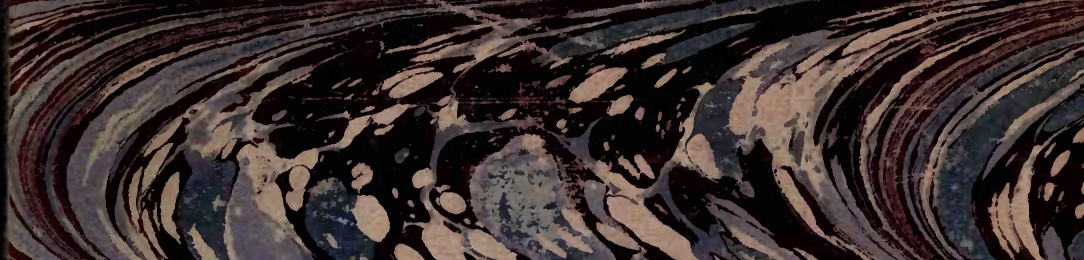

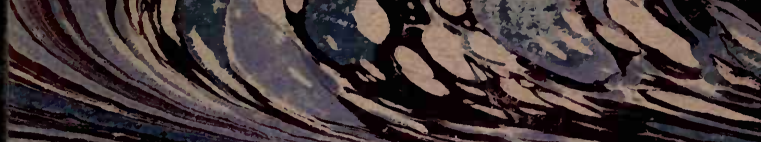

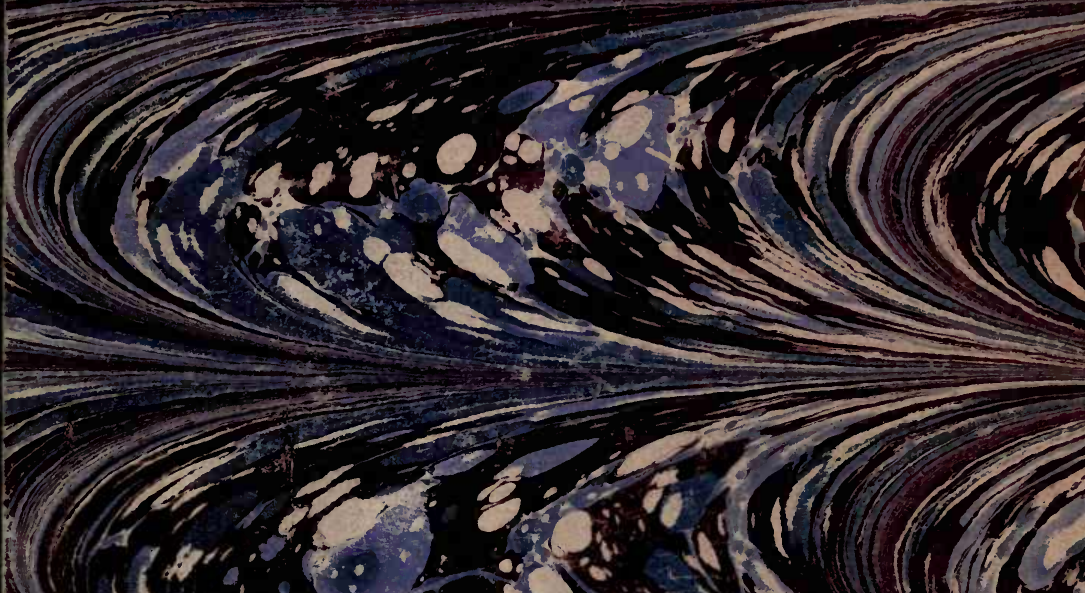
Nolition

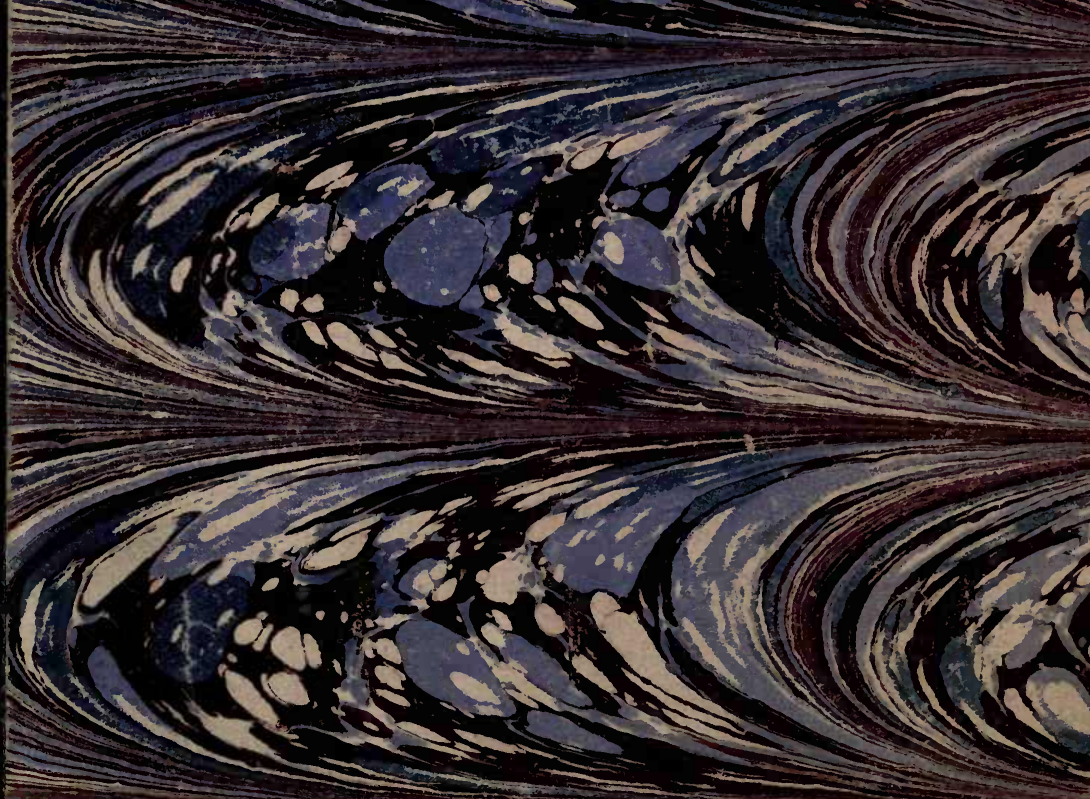




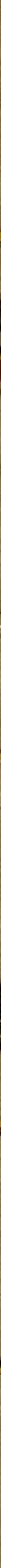




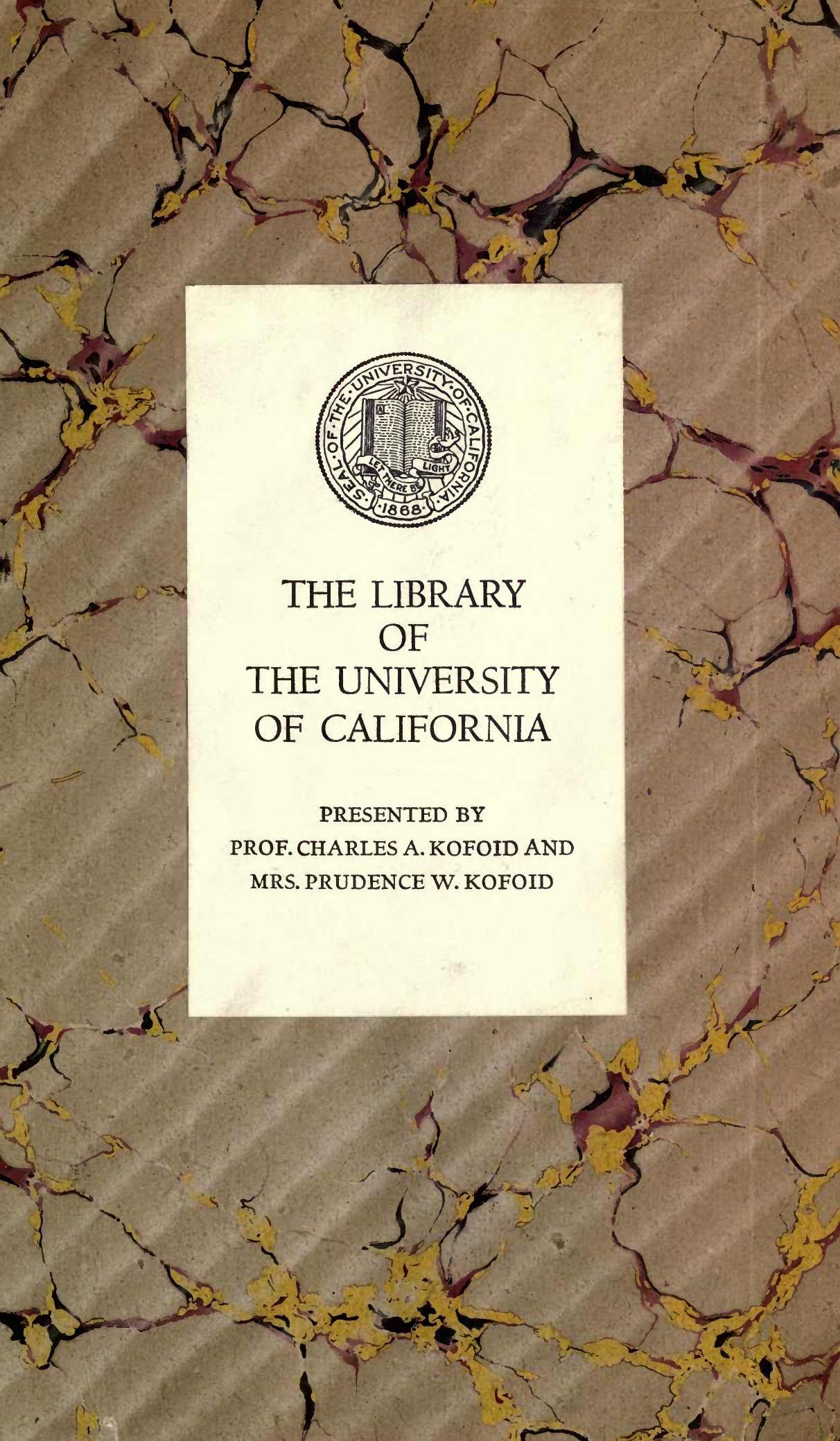






$x^{2}+x^{2}=1000$ 


\section{OCEAN LIFE;}

BY

JAMES M. SOMMERVILLE, M. D.,

Member of the Academy of Natural Sciences

or

Philadelphia.

"THERE'S BEAUTY IN THE DEEI"."

PHILADELPHIA :

BARNARD \& JONES, PRINTERS, No. 510 MINOR STREET, (RIDGWAY BUILDINGS.)

1858. 
Entered, according to the Act of Congress, in the year 1859, by JAMEs M. Sommerville, M. D., in the Clerk's Office of the District Court of the United States in and for the Eastern District of Pennsylvania. 


\section{INTRODUCTION.}

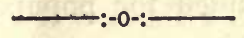

The SeA, which is the least explored of Nature's realms, holds within it a wonderfully organized world, peculiar to itself. It abounds with a living flora and fauna, which, though obscure and strange, are equally beautiful and useful. An endeavor has been made to exhibit in one group, representations of some of the most interesting submarine forms, occurring in southern latitudes, off the coasts of America; observing their forms, colors, and habits, so truthfully, that the plate shall prove of value to the lover of nature, and afford delight and instruction, to the intelligent mind and cultivated taste. Seventy-five species of the lower forms of vegetable and animal life are shown of their natural size, and as they appear in their native element. The grouping may be considered, rather as an intellectual truth, than as a literal view.It might be termed a mental oasis of the sea.-And it should be remembered that the floor of the ocean is not every where adorned with such forms of beauty. On the contrary, it has its seeming wastes of vast extent, as well as the dry land. But even in those apparent deserts, the plummet has revealed myriads of minute Diatomaceoe. In looking down from a boat, through moderately clear water, I have observed a floor so desolate, that my first impulse was to pronounce it a cheerless blank; but on drawing the dredge, it has afforded a rich variety of objects of great interest. 
Yet there are many places, especially in the shallower waters, densely clothed with forests of sea-plants, which are inhabited by numerous and varied representatives of the animal kingdom. It is astonishing, how many living species may be found in a small tide-pool, where circumstances have favored their necessities. In the Tableau, however, no attempt has been made to exhibit congruous forms, or even those from waters of the same temperature. The objects have been taken (as will be seen by reference to the key,) from localities widely separated, and are brought together with regard to their habits; so as to set forth, (with the aid of the text,) their peculiarities, and their positions, and relations to each other, in their respective classes, and to show the dependence of the great kingdoms upon each other.The work is chiefly intended for popular use; and the hope is humbly indulged, that it may prove an aid, and an incentive to. the great study of comparative zoology; an acquaintance with which seems indispensable to a comprehensive knowledge of mankind. The description of the plate is so arranged that the reader will be conducted from the investigation of the lower forms of life, (as they appear to us,) to those more complicated in structure.

The picture was executed in water colors by Mr. C. Schuessele, and it is with much pleasure that $I$ acknowledge his superior qualifications as an artist. I am also happy to speak in the highest terms of praise, of the abilities of Mr. F. Moras, who reproduced the Tableau in a very superior style of chromo-lithography. I would likewise gratefully express my obligation for valuable suggestions, to Mr. James Hamilton, the distinguished marine and landscape painter. In offering the work to the public; I do not pretend that it has reached perfection, neither am I confident that its accuracy is faultless; yet every effort has been made to render it a truthful and acceptable medium for imparting knowledge. Any errors which may have crept in while passing through the hands of the different operators, (if conscious of them,) I have corrected by drawings in the pamphlet. The text is chiefly compiled from the writings of European authors of celebrity. I have been guided in making the selections, which are from many sources, by my own observations upon living objects; 
and have endeavored to make the description as comprehensive as the limits of the volume would admit; hoping that many may derive pleasure and profit from the investigation of these inhabitants of the sea, and that some may be induced to go forth and reveal new facts in the economy of nature; expounding the wonderful constructions and important uses, which are hidden in the humblest of the Creator's works.

While some of the objects pictured have been drawn from Nature, expressly for the Tableau; yet for others which were beyond my reach, I am principally indebted to the government publications of Europe and America.

James M. Sommerville, M. D.

\section{A U THORITIES.}

Nereis Boreali Americana. By William II. Harvey, M. D.General Outline of the Animal Kingdom. By T. Rymer Jones, F. R. S.-Edinburgh Philosophical Journal. Dr. Grant.-History of British Sponges. By George Johnson, M. D.-Manual of Marine Zoology. By P. H. Gosse.-Report of British Association, 1834. Sir John Dalyell.-British Zoophytes. By Dr. G. Johnston.-Prof. A. De Quatrefages.-G. B. Sowerby, F. L.S.U. S. Exploring Expedition, Zoophites. By Prof. James D. Dana.-Histoire Naturelle Des Zoophytes, Par René Primevère Lesson.-Philosophical Transactions, 1773. Actinia.-Transactions of the Microscopical Society of London.-Encyclopedia Londinensis. Actinia.-Ann. and Mag. of Natural History, 1855. Crustacea.-Lectures on the Comparative Anatomy and Physiology of the Invertebrate Animals. ByRichard Owen, F. R. S.-History of British Star-fishes, \&c. By Edward Forbes.S. P. Woodward's Manual of the Mollusca.-Siebold's Comp. Anat. of Invertebrata.-Voyage daus L'Amérique Méridionale, \&c., Par Alcide D'Orbigny.-Hand-book of Zoology. By Prof. J. Van Der Hoeven.-Le-Règne Animal par Georges Cuvier.Histoire Naturelle de L'Ile De Cuba, par M. Ramon De La Sagra.-History of British Fishes. By Willian Yarréll, F.L.S., and my own observations.

J. M. S. 


\section{OCEA N L I FE.}

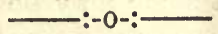

ALG办. - SEA-WEEDS.

1. Caulerpa Mexicana.

2. Halimeda incrassata.

3. Udotea conglutinata.

4. Udotea conglutinata-young.

5. Acetabularia crenulata.

6. Chamædoris annulata.

7. Halidrys osmundacea.

8. Padina pavonia. (Peacock's tail.)

9. Zonaria lobata. (Torn fan.)

10. Dictyota ciliata.

11. Hydroclathrus cancellatus,

12. Bostrychia Montagnei.

13. Dasya Wurdemanni.

14. Champia salicornoides.

15. Delesseria involveus. '

16. Botryoglossum platycarpum.

17. Eucheuma isiforme.

18. Liagoza valida.

19. Gigartina microphylla. .

20. Gigartina spinosa.

21. Chrysymenia Agardhii.

22. Chrysymenia uvaria.

23. Prionitis lanceolata.

24. Grateloupia Gibbesii. .

25. Centroceras clavulatum.

PORIPHORA.

26. Spongio tubulosa. (Sponge.)

Florida.
Key West, Florida.

Key West, “

Key West, "

Key West, "

Key West, " "

Key West, “"

California.

Sand Key, Florida.

Key West, " "

Key West, "

Sand Key, "

Key West, "

Key West, "“

Key West, "

Key West, "6

Monterey California

Key West, Florida.

Sand Key, "“

Monterey California

California.

Key West, Florida.

Key West, “"

California.

Key West, Florida.

Key West, "6

POLYPES.

27. Sertularia pinaster. Garland of cups. Florida.

28. Gorgonia crassa.

Florida.

29. Renilla americana. Throne of stars. Off Rio Janeiro. 
30. Actinia rubus.

31. Actinia primula.

32. Actinia achates.

33. Actinia Florida.

34. Actinia pluvia.

35. Actinia rhodora.

36. Actinia pustulata.

37. Metridium prætextum,
Valparaiso, Chili.

Off San Lorenzo.

Coast of Patagonia.

San Lorenzo, off Callao, Peru.

San Lorenzo, Callao, Hospital Island, Rio de Janeiro.

Praya Grande Fort, Harbor of Rio de Janeiro.

ACALEPHA.

38. Physalia pelagica,

Portuguese man-of-war. Atlantic Ocean.

ECHINODERMATA.

39. Ophiocoma rosula.

Sand Star, Key West.

40. Ophiocoma echinata.

Brittle Star, E. Florida.

41. Asterias sentus,

Round-rayed Star-fish, K. West.

42. Echinus. (Sea urchin.) Key West, Florida.

43. Cast off shell of Sea-urchin. Key West, "

44. Holothuria Peruviana. (Sea cucumber.) Coast of Peru.

CRUSTACEA.

45. Rhynchocinetus typus. Prawn, Leaping. Coast of Valparaiso. 46. Palæmon Gaudichaudii. (Prawn.) Coast of Chili.

17. Pinnotheres Chilensis. (Golden crab.) Coast of Valparaiso. 48. Pilumnoides perlatus. Coast of Peru.

49. Porcellana egregia. Antilles.

50. Porcellana acanthophora.

Coast of Valparaiso.

CIRRIPEDIA.

51. Balanus semiplicatus. Acorn Barnacle. Atlantic Ocean. Meridian.

52. Tetraclita porosa. (var. Elegans.) Common Barnacle. West Indies.

53. Pollicipes ruber. (Stalked Barnacle.) West Coast of Mexico. CONCHIFERA.

54.. Mytillus hamatus. (Mussel.) Gulf of Mexico. 55. Pecten ornatus. (Decorated Scallop.) East Florida. 56. Pecten purpuratus. (Scallop.) Gulf of Mexico. 57. Pecten laqueatus. Guttered scallop. California. 
GASTEROPODA.

58. Eolidia Patagonica. (Sea-mouse.) Coast of Patagonia.

59. Eolidia inca. (Sea-mouse.) Coast of Chili.

60. Doris Peruviana. (Little Doris.) Coast of Lima.

61. Doris Fontainii. (Great Doris.) Coast of Chiti.

62. Aplysia livida. (Sea Hare.) Rio de Janeiro.

63. Fissurella costata. Key-hole, Limpet. Coast of Chili.

64. Fissurella Patagonica. Umbrella shell. Coast of Patagonia.

65. Trochus araucanus. ('Top shell.) Coast of Valparaiso.

66. Littorina Peruviana. (Winkle.) Coast of Chili.

67. Scalaria lineata. . Florida.

68. Natica limbata. Coast of Patagonia.

69. Sigaretus neritoideus. - - Coast of Peru.

70. Voluta angulata. B Bay of San-Blas.

71. Murex Patagonicus. (Rock Shell.) Bay of San-Blas,

72. Cancellaria tuberculosa. Patagonia. Coast of Peru.

PISCES. - FISHES.

73. Hippocampus punctulatus. (Little Sea Horse.)

74. Fistularia tabacaria. (young) Tobacco-pipe-fish.

Gulf of Mexico.

75. Clepticus creolus.

Coast of Brazil.

Antilles. 


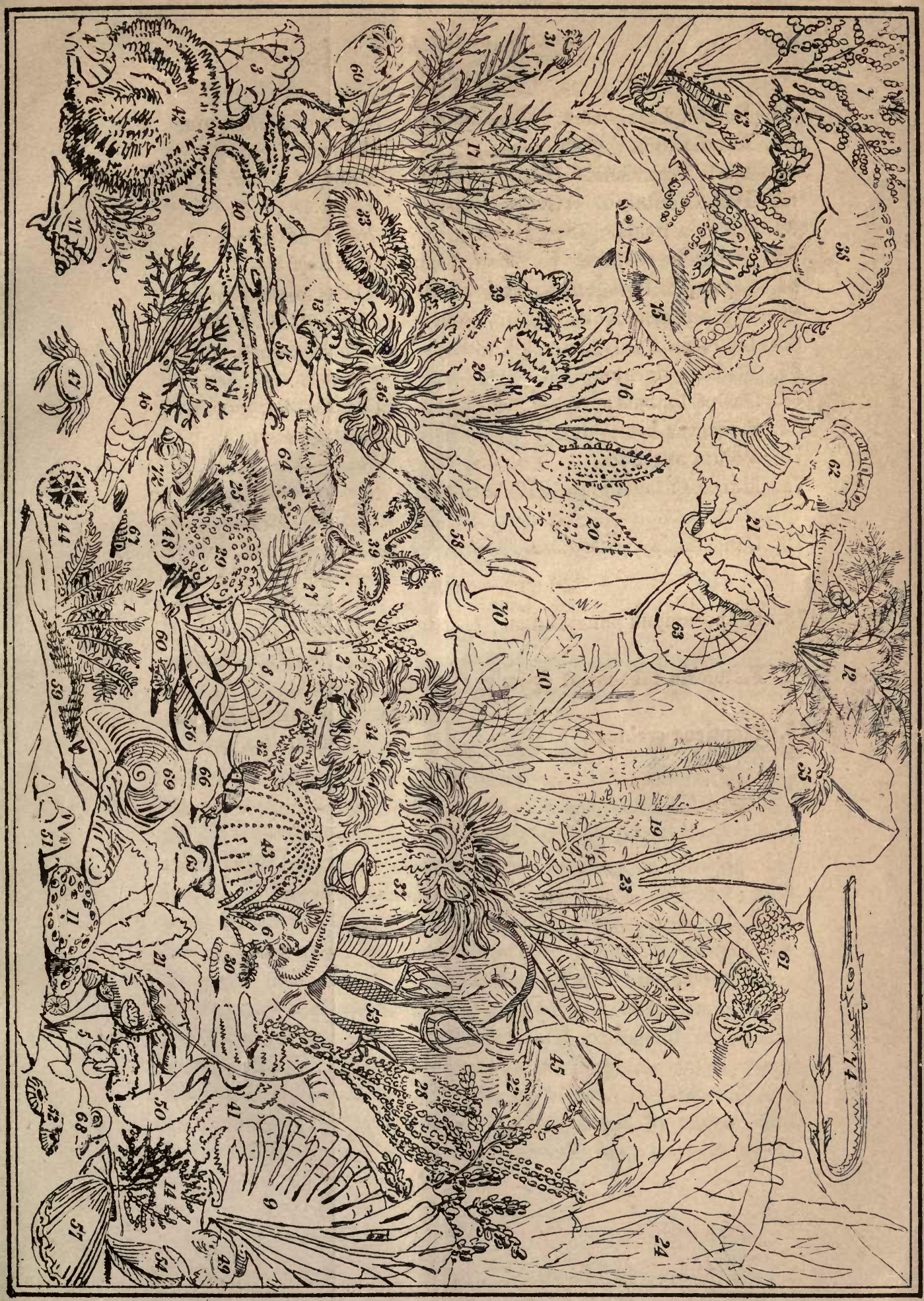




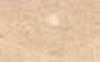




\section{$0 \mathrm{CEAN}$ LIFE.}

A L G $\mathbb{E}$.

THe Sea-weeds belong to the cellular order of vegetables, and to the Cryptogamic class of the Linnæan system. The term Algæ, is applied to a vast class of aquatic plants, many of which are inhabitants of fresh water. But the highest forms are those popularly termed Sea-weeds.

"The root among the Algæ is rarely much developed. They do not, in a general way, derive nourishment from the soil on which they grow. We find them growing indifferently on rocks of various mineralogical character, on floating timber, on shells, on iron, or other metal, on each other-in fine, on any substance which is long submerged, and which affords, a foothold. Into none of those substances do they emit roots, nor do we find that they cause their decay, or appropriate to themselves the constituents of these substances. They are nourished by the water that surrounds them, and the various substances which are dissolved in it."

"On whatever substance the Algæ may feed, it is rarely obtained through the intervention of a root. Dissolved in the water that bathes the whole frond, the food is imbibed equally through all the cells of the surface, and passes from cell to cell toward those parts that are more actively assimilating, or growing more rapidly. The root, when such an organ exists, is a mere holdfast, intended to keep the plant fixed to a base, and prevent its being driven about by the action of the waves. It is ordinarily a simple disc or conical expansion of the base of the stem, strongly applied and firmly adhering to the substance on which the Algæ grows. This is the usual form among all the smaller growing kinds. When, however, as in the gigantic Oar-weeds, the frond attains a large size, offering a proportionate resistance to the waves, the central disc is strengthened by lateral holdfasts or discs formed at the bases of side roots emitted by the 
lower part of the stem. The only instances of penetrating roots among the Algr, with which I am acquainted, occur in certain genera of Sophoneæ and in the Caulerper, tropical and sub-tropical forms. But neither in these cases do the roots appear to differ from the nature of holdfasts, and their ramification and extension through the sand is probably owing to the unstable nature of such a soil. It is not in search of nourishment, but of stability, that the fibres of their roots are put forth, like so many tendrils."

Three principal varieties of color are generally noticed among the Algæ, namely: grass-green or herbaceous, olive-green, and red. In the sub-division of Algæ into three groups, the color of the frond is employed as a convenient diagnostic character. The sea, in all explored latitudes, has a vegetation of Algæ. Towards the poles this is restricted to microscopic kinds, but almost as soon as the coast rock ceases to be coated with ice, it begins to be clothed with Fuci. Climate has an effest on the Algæ as upon all other organic bodies, though its influence is less perceptible in them than in the terrestrial plants, because the temperature of the sea is much less variable than that of the air. Still, as the temperature of the ocean varies with the latitude, we find in the marine vegetation a corresponding change; certain groups being confined to the colder regions of the sea, and others only regetating where the mean temperature is considerable. The uses of the Algæ may be considered under two points of view, namely: the general office which this great class of plants, as a class, discharges in the economy of nature ; and those minor useful applications of separate species which man selects on discovering that they can yield materials to supply his various wants. The part committed to the Algr in the household of nature, though humble when we regard them as the lowest organic members in that great family, is not only highly important to the general welfare of the organic world, but, indeed, indispensable. This we shall at once admit, when we reflect on the vast preponderance of the ocean over the land on the surface of the earth, and bear in mind that almost the whole submarine vegetation consists of Algæ.

It is one of the laws of nature, that animals shall feed on 
organized matter, and vegetables on unorganized. For the support of animal life, therefore, we require vegetables to change the mineral constituents of the surrounding media into suitable nutriment. In the sea this office of regetation is almost exclusively committed to the Algæ, and we may judge of the completeness with which they execute their mission by the fecundity of the animal world which depends upon them. Not that I would assert that all, or nearly all, the marine animals are directly. dependent on the Algæ for their food; for the reverse is notoriously the case. But in every class we find species which derive the whole or a part of their nourishment from the Algr; and there are myriads of the lower in organization which do depend upon them altogether. Among the higher orders of Algæ feeders I may mention the Turtles, whose green fat, so prized by Aldermanic palate, may possibly be colored by the unctuous green juices of the Caulerpæ, on which they browse. But without further notice of those that directly depend on the Algæ, it is manifest that all must ultimately, though indirectly, depend on whatever agency in the first instance seizes on inorganic matter, and converts it into living substance suitable to enter into the composition of animal nerve and muscle. And this agency is assuredly the office of the vegetable kingdom, here confined in the main to Algæ; proving that they are indispensable to the continuance of organic life in the sea. They also keep pure the water in which they vegetate, and yield a considerable portion of oxygen gas to the atmosphere.

The Algæ have served as food both for man and cattle; and have been much employed in agriculture and the arts. But they have proved most valuable to man, in affording substances which prove highly beneficial in the treatment of disease. 


\section{P O R I P O R A.}

There are certain forms of organization so closely allied to both the animal and vegetable kingdoms, that it is difficult to say precisely in which they ought to be included. Such are the Sponges, which, although by common consent admitted into the animal series, will be found to be excluded, by almost every point of their structure, from all the definitions of an animal hitherto devised. What is an animal? How are we to distinguish it as contrasted with a mineral or a vegetable? The concise axiom of Linnæus upon this subject is well known:- "Stones grow; vegetables grow and live; animals grow, live, and feel." The capability of feeling, therefore, formed, in the opinion of Linnæus, the great characteristic separating the animal from the vegetable kingdom; yet, in the class before us, no indication of sensation has been witnessed; contact, however rude, excites no movement or contraction which might indicate its being perceived; no torture has ever elicited from them an intimation of suffering; they have been pinched with forceps, lacerated in all directions, bored with hot irons, and attacked with the most energetic chemical stimuli, without shrinking or exhibiting the remotest appearance of sensibility.

On the other hand, in the vegetable world we have plants which apparently feel, in this sense of the word. The sensitive plant, for example, which droops its leaves upon the slightest touch, would have far greater claims to be considered as being an animal than the Sponges, of which we are speaking. The best definition of an animal, as distinguished from a vegetable, which has yet been given, is, that whereas the latter, fixed in the soil by roots, or immersed perpetually in the fluid from which it derives its nourishment, absorbs by its whole surface the nourishment which it requires; the animal being, generally, in a greater or less degree capable of changing its position, is provided with an internal receptacle for food, or stomachial cavity, from whence, after undergoing the process of digestion, the nutricious matter is taken up. But, in the case of the Sponge, no such reservoir is found, and in its place we find only anastamosing canals which 
permeate the whole body, and convey the circumambient medium to all parts of the porous mass.-T. Rymer Jones.

In a work entitled "Principles of Zoology, by L. Agassiz and A. A. Gould," 1856, it is stated, "The Sponges have so great a resemblance to some of the polypi, that they have been classed among animals, although in reality they belong to the vegetable kingdom."

Dr. George Johnson says:- "Sponge is a light, elastic, porous substance, formed of interlaced horny fibres, producing, by their numerous inosculations, a rude sort of net work, with meshes or pores of unequal size, and usually of a square or rounded angulated figure. Besides these pores, there are some circular holes of a larger size (Oscula), scattered over the surface of most Sponges, and which lead into sinuous canals that permeate their interior in every direction. The oscula, canals and pores, communicate freely together, for the structure of the Sponge is alike throughout the mass, or at most the texture of the surface is merely a little more compact than the inner parts. The characteristic property of Sponge is the facility with which it imbibes a large quantity of any fluid, more especially of water, which is retained amid the meshes until forced out again by a sufficient degree of compression, when the specimen returns elastic to its former bulk. From this peculiarity, combined with its pleasant softness, arises the value of Sponge, (the dried Sponge is only the skeleton of the living animal.) When the Sponge is living and recent, its canals and pores are filled with a glairy, colorless fluid, like the white of an egg, which flows freely out on the removal of the Sponge from the water. The quantity of this fluid varies according to the species. In some it is copious, even to nauseousness, but in the compact Halichondriæ there is little of it, and in the firm, inelastic, and calcareous Grantiæ it appears to be entirely wanting.". "It has an unctuous feel, emits a fishy odor when burnt, leaves a thin film or membrane when evaporated, and appears to the naked eye transparent, colorless, and homogeneous, like the colorless part of an egg; but when a drop of it is examined on a plate of glass, under the microscope, it appears entirely composed of very minute, transparent, spherical or ovate granules, like monades, with some moisture. These 
monade-like bodies, nearly all of the same size and form, resemble the pellucid granules or vesicles, which Trembley has represented as composing the whole texture of the Hydræ, or the soft granular matter we observe in the stems of living Sertulariæ; and, indeed, most of the fleshy parts of organized bodies appear to be composed of similar pellucid, granular, or monade-like bodies in different states of aggregation." The composition of the skeleton or fibrous portion of the Sponge is remarkably diversified. Its liquid food is not received into any cavity, but permeates to all points, and is equally elaborated in every part of the system, which, in one sense, is an unconfined digestive cavity, where the various ingredients are selected, separated, and fitted for appropriation by each species, agreeably to its nature. For example, it is very common to find growing on the same rock or sea weed, a siliceous, a calcareous, and a horny sponge; they have all the same exposure, and are all recipients of the same nutriment, yet does each act upon this differently. One extracts from the fluid silica, which it causes to assume a solid crystalline form; another selects, in the same manner, the calcareous particles which obedient to the laws of life, assume figures novel to them in their mineral state; and, again, another rejects both the lime and the flint as injurious to its constitution. Sponges appear to be true Zoophytes, and it imparts additional interest to their study to consider them, as they possibly are, the first matrix and cradle of organic life, and exhibiting before us the lowest organizations compatible with its existence.

Dr. Grant, to whom we are chiefly indebted for the physiology of Sponge, was the first to establish the fact of a continued current (except when interrupted by the will of the animal,) moving from without into the interior of its body, and thence passing through large channels to find an exit by the oscula or mouths again, from the exterior surface. Dr. Grant observes:- "I put a small branch of Spongia coalita, with some sea water, into a watch glass, so as to bring one of the apertures on the side of the Sponge fully into view under the microscope, and I beheld for the first time the splendid spectacle of this living fountain vomiting forth, from a circular cavity, an impetuous torrent of liquid matter, and hurling along, in rapid succession, opaque 
masses, which it strewed every where around. The beauty and novelty of such a scene in the animal kingdom long arrested my attention; but, after twenty-five minutes of constant observation, I was obliged to withdraw my eye from fatigue, without having seen the torrent for one instant change its direction, or diminish in the slightest degree the rapidity of its course. I continued to watch the same orifice, at short intervals, for five hours-sometimes observing it for a quarter of an hour at a time-but still the stream rolled on with a constant and equal velocity; the current then gradually diminished, and ceased in about an hour." Dr. Grant, in referring to experiments made with the crumb of bread sponge, (Halichondria panicea,) a common species on the British coast, remarks:- "Two entire round portions of this Sponge were placed together in a glass of sea water, with their orifices opposite to each other at the distance of two inches; they appeared to the naked eye like two living batteries, and soon covered each other with feculent matter. I placed one of them in a shallow vessel, and just covered its surface and highest orifice with water. On strewing some powdered chalk on the surface of the water, the currents were visible at a great distance; and on placing some small pieces of cork, or dry paper, over the apertures, I could perceive them moving by the force of the current at the distance of ten feet from the table on which the specimen rested. Naturalists have long suspected the presence of very minute cilia in the gelatinous flesh of the sponge, and were inclined to attribute the currents to their agency; but as yet, they had been unable to detect them by the closest scrutiny, when Dr. Dobie, and afterwards Mr. Bowerbank, discovered them in motion in living Sponges. It was in the sack Sponge, (Grantia compressa,) which has the form of a little flattened bag, of an angular outline, of a whitish hue, with an orifice at each angle, that the experienced eyes of these gentlemen detected the moving cilia. "By tearing specimens in pieces, (for the use of the keenest cutting instruments so crushed the texture as to destroy the parts,) and examining the separated edges, with high powers, Mr. Bowerbank found that the sides are composed of a number of hexagonal cells, defined by the peculiar arrangement of the triradiate spiculæ, and having their walls formed by a 
number of nucleated granules; these angular cells are laid at right angles to the long axis of the Sponge, extending from the outer surface to the inner, and they are crossed near the middle by a thin partition, perforated in the centre. In this perforation, several long, whip-like cilia were seen lashing with energy, and the same organs were afterwards found to be connected with the granules of which the cell walls were composed. By means of the waving of these cilia, then, the water is made to flow through the cells from without, being discharged into the interior of the sack and poured out in streams through the oscula or openings which terminate the angles of the Sponge."

This experiment, we think, leaves no doubt of the animal nature of Sponge. "If a Sponge be mechanically divided into several pieces, every portion becomes a distinct animal. The multiplication of Sponges, however, is effected in another manner, which is the ordinary mode of their reproduction, and forms a very interesting portion of their history. At certain seasons of the year, if a living Sponge be cut to pieces, the channels in its interior are found to have their walls studded with yellowish gelatinous granules, developed in the paranchymatous tissue; these granules are the germs or gemmules from which a future race will spring; they seem to be formed indifferently in all parts of the mass, sprouting, as it were, from the albuminous crust that coats the skeleton, without the appearance of any organs especially appropriated to their development.

As they increase in size they are found to project more and more into the canals ramifying through the Sponge, and to be provided with an apparatus of locomotion, of a description such as we shall frequently have occasion to mention.

The gemmule assumes an ovoid form, and a large portion of its surface becomes covered with innumerable vibrating hairs, or cilia, as they are denominated; these are of inconceivable minuteness, yet individually capable of exercising rapid movements, whereby they produce currents in the surrounding fluid. As soon, therefore, as a gemmule becomes sufficiently mature, it becomes detached from the nidus where it was formed, and, being whirled along by the issuing streams, is expelled through the fecal orifices of the parent, and escapes into the water around. 
Instead, however, of falling to the bottom, as so apparently helpless a particle of jelly might be expected to do, the ceaseless vibration of the cilia upon its surface propels it rapidly along, until, being removed to a considerable distance from its original, it attaches itself to a proper object, and, losing the now useless locomotive cilia, it becomes fixed and motionless, and develops within its substance the skeleton peculiar to its species, exhibiting by degrees the form of the individual from which it sprung.

It is curious to observe the remarkable exception which Sponges exhibit to the usual phenomena witnessed in the reproduction of animals, the object of which is evident as the result is admirable. The parent Sponge, deprived of all power of movement, would obviously be incapable of dispersing to a distance the numerous progeny which it furnishes. They must inevitably have accumulated in the immediate vicinity of their place of birth, without the possibility of their distribution to other localities.

The seeds of vegetables, sometimes winged and plumed for the purpose, are blown about by the winds, or transported by various agencies to distant places; but in the present instance, the still waters in which Sponges grow would not have served to transport their progeny elsewhere; and germs so soft and delicate could hardly be removed by other creatures. Instead, therefore, of being helpless at their birth, the young Sponges can, by means of their cilia, row themselves about at pleasure, and enjoy for a period, powers of locomotion denied to their adult state.

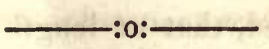

\section{ZOOPHYTES OF OLD AUTHORS.}

PoLYPS are gelatinous, oblong, or conical animals, with a contractile body, an intestinal cavity, and an oval aperture, which is surrounded by a circlet of arms or tentacles. Besides these arms, there are no special organs of sense, at least in the greater 
number of Polyps, though all appear to be very sensible to the stimulus of light. Propagation is effected partly by eggs, partly by germs or buds; in many instances the last are not detached from the parent stem, and thus there arise compound animals, different individuals being connected. Our Polyps were, for the most part, unknown to the ancients, and under this name entirely unknown. By it they understood naked molluses of the form of the sepia, especially that genus which is now called Octopus by Zoologists. From analogy, and from some resemblance of form, Réaumer and Jussieu first gave the name, Polyp, to those fresh water animals that had been described by Trembley, and which were provided with a circlet of arms.

To this class belong many marine animals, which, at first sight, rather resemble plants than animals. Formerly, these so-called sea plants were, on account of the hardness of the calcareous substance of which they consist, referred to the mineral kingdom, and corals were compared to branching crystallizations (Arbor Dianæ) and stalactites.

The ancients believed that corals were soft whilst in the sea, and only became hard in air.

Even among later authors, traces may be found of the same opinion, founded on defective observation, or on confusion of soft species with hard ones.

Up to the middle of the last century, it was the prevailing view that these corals belonged to the regetable kingdom. Marsigli, in 1706, observed, on the shore of the Mediterranean, some of these products, (Alcyonium, Corallium, Antipathes,) and found in their pores little bodies that contracted when the stem was removed from the water. Such bodies, or buds, he took to be flowers, and so believed, that at length the view was definitely established, which consigned these marine products to the vegetable kingdom. But still, the animal odor which was observed, opposed this view, as well as the chemical investigations of Geoffroy, of Lemery, and of Marsigli himself, which demonstrated ammoniacal constituents in the supposed sea-plants, just as in animal substances. Peysonnel, a physician of Marseilles, in 1723, upon repeated examinations, found Marsigli's plants to be animals. 
Réaumer thought this notion very improbable, but after the discovery was confirmed by Trembley and Bernard de Jussieu, (a celebrated botanist, he adopted the views of Peysonnel, and Linnæus accordingly transferred the coral and stone plants to the animal kingdom. Polyps are either naked, or are provided with a body more or less hard, which they surround like a bark, or by which they are surrounded.

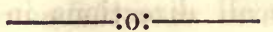

SERTULARID E.

In the Sertularian Hydrozoa, the fleshy substance of the animal is inclosed in a ramose, horny sheath, which it traverses like the pith of a tree, following all of the ramifications of the branched stem or polypary. The general stem of the polypary is entirely filled with a fleshy substance, exactly resembling, in its nature, the tissue composing the body of the polyp, whereby all the individuals belonging to the common stock are brought into communication with each other. "The Hydroida excel all other Zoophytical productions in delicacy, and the graceful arrangement of their forms, some borrowing the forms of the prettiest marine plants, others assuming the semblance of the ostrich plume, while the variety and elegance exhibited in the figures and sculpture of their miniature cups and chalices is only limited by the number of their species."

In the Sertularido, "the whole compound animal is inclosed in a tube of transparent substance, somewhat flexible, though firm, resembling horn, an exudation from the gelatinous integument, and this tube, at every bud, takes the form of an open cell or cup, (varying much in shape, according to the species,) into the cavity of which each individual polyp head can withdraw itself on alarm, and from the orifice of which it protrudes and expands when seeking prey.

These little Polyps provide nourishment for the whole. On examining a piece of one of these polyparies with a good glass, 
the tubular horny envelope is seen to be filled with granular matter, and on attentively watching it, globules will be seen moving in different directions, producing a sort of circulation, or cyclosis, very much resembling what is observable in some plants. The globules thus moving, do not appear to be contained in vessels, but steal in slow currents, ascending along the sides and returning down the middle in an opposite direction.

It is interesting to view these Polyps with a microscope: "Protruding themselves beyond the mouths of their cells, they inflect their bodies in all directions in quest of prey, waiting until some passing body impinges upon their tentacula, which is at once seized and conveyed into the stomach with a rapidity and dexterity almost beyond belief. The multiplication of these singular animals appears to take place in three different modes: first, by cuttings, as in plants ; second, by offshoots, or the formation of new branches bearing Polyps; and, third, by gemmules capable of locomotion. The first mode strikingly resembles what is observed in the vegetable kingdom; for, as every branch of the plant-like body contains all the parts necessary to independent existence, it can hardly be a matter of surprise that any portion, separated from the rest, will continue to grow and perform all the functions of the entire animal.

"The second mode of increase, namely, by the formation of new branches and Polyps, seems more like the growth of a plant than the development of an animal. We will consider it under two points of view : first, as regards the elongation of the stem; secondly, as relates to the formation of fresh cells containing the nutritive Polyps. On examining any growing branch, it will be found to be soft and open at the extremity, and through the terminal orifice, the soft tegumentary membrane above described, as forming the tube, is seen to protrude; the skeleton is not, therefore, merely secreted by the inelosed living granular matter, but it is the investing membrane, which continually shoots upwards and deposits hard material in its substance, as it assumes the form, and spreads into the ramifications peculiar to its species.

"Having thus lengthened the stem to a certain distance, the next step is the formation of a cell and a new Polyp, which is accomplished in the following manner: The newly formed branch 
has at first precisely the appearance and structure of the rest of the stalk of the Zoophyte, being fillea with granular matter, and exhibiting in its interior the circulation of globules already described, moving towards the extremity along the sides of the tube, and in an opposite course in the middle; the end of the branch, however, before soft and rounded, soon becomes perceptibly dilated. After a few hours, the branch is visibly longer, its extremity more swollen, and the living pith is seen partially to have separated itself from the sides of the tube, the boundaries of which become unore defined and undulating. The growth still proceeding, the extremity is distinctly dilated into a cell, in which the soft substance seems to be swollen out, so as to give a rude outline to the bell-shaped Polyp, but no tentacula are yet distinguishable. A rudimentary septum is now visible, stretching across the bottom of the cell, through the centre of which the granular matter, now collected into a mass occupying but a portion of the stem, is seen to pass. The Polyp and cell gradually grow more distinct, and the tentaculæ become distinguishable. As the development proceeds, the tentaculæ become more perfect, and the Polyp at length rises from its cell to exercise the functions for which it is destined. The third mode of multiplication, or that by reproductive gemmules, seems to be especially adapted to the diffusion of the species, and is peculiar to Zoophytes of this description. At certain periods of the year, besides the ordinary cells which contain nutritive Polyps, others are developed from different parts of the stems, which may be called female or fertile Polyps, although usually simply termed the vesicles. The cells of this kind are much larger than the nutritive cells, and of very different forms; they are, moreover, deciduous, falling off after the fulfilment of the office for which they are provided. They are produced in the same manner as the rest of the stem, by an extension of the tegumentary membrane, which, as it expands into the form of the cell, becomes of a horny texture. It may be traced, however, over the opening of the cavity, where it sometimes forms a movable operculum."

Now, within this tall, transparent, vase-like capsule, by a series of gradual changes, the common nutrient flesh develops a very peculiar embryo. "When somewhat mature, the permeating tube 
is seen swollen out into separate ovate sacks, ten or more in number, each of which contains several embryos. Those nearest the mouth of the vesicle are first developed, and escape successively by slowly emerging from the pitcher-like rim." This little medusa-like creature, freed from its parent cell, has the power of moving about rapidly in all directions through the water.

Mr. Peach, who first observed them, says:- "They resemble umbrellas without handles, or very wide and short hand bells." He also remarks:- "They assume various positions, and, when in the water, remind me of thousands of parachutes thrown from a balloon, descending in various states of expansion." 'The phenomena of which we have spoken, strikingly illustrate the law known as "the alternation of generations," and may be briefly summed up as follows:- "The Polype, a fixed and rooted animal, increases its own individual life for awhile, by putting forth a succession of budding heads, but at a certain period gives birth to a number of beings that bear no resemblance to itself in form or habit, but are, to all intents and purposes, free, swimming medusæ. Each of these, after pursuing its giddy course for a time, produces a number of eggs, which change into active animals, having the closest resemblance to infusoria. Each of these latter presently becomes stationary, and affixed to some foreign body, along which it creeps as a root thread, shooting up tubular and celled Polypes.

"Hence, any one individual is not at all like its mother or its daughter, but exactly resembles its grandmother or its granddaughter." In other words, the alternations are as follows:1. The medusa produces eggs. 2. The eggs, after passing through an infusorial state, become Polypes, like Corynæ, Tubulariæ, or Campanularix. 3. The Polype produces a kind of bud that finally drops off and becomes a medusa. Thus, the egg of a Medusa, in such cases, does not produce a Medusa except after going through the intermediate state of the Polype. Or, if we commence with the Polype, the series is: 1 . The Polype produces bulbs that become Medusæ. 2. The Medusæ produce eggs. 3. The eggs produce Polypes. 


\section{A NTHOZOA ASTEROIDA.}

Gorgonide.-THE generic characters of Gorgonia are thus described by Johnson. "Polype, mass rooted, arborescent, consisting of central axis, barked with a polypiferous crust; the axis, horny, continuous, and flexible, branched in co-equality with the polype mass; the crust when recent, soft and fleshy, when dried, porous and friable; the orifices of the polype cells, more or less protuberant."

In the Hydroid Zoophytes, it was observed that the horny skeleton formed, as it were, a case, or external support for the fleshy part of the animal and its polypes, which in the asteroid groups, included in the families of Pennatulidæ and Gorgonidæ, the skeleton consists of a central horny or calcareous axis, around which are arranged the polype, bearing fleshy parts. "These horn plants grow with the stem and branches upwards; the latter are usually situated in a plane and often coalesce. Many earlier and later writers, have believed the stem to be a plant, on which polypes had fixed themselves. In the Gorgonia, a beautiful frame-work of horny matter, consisting of a stem, and a minute net work of branches, occupies the centre of the structure; and this is clothed with a soft flesh, through which the channels pass that connect the polypes together. This plant is covered with a firm skin, in which a great amount of earthy crystals is deposited, so as to form a crust, and in this, are the hollows or cells by which the polypes are protected. In the dead structures with which we are familiar, under the name of sea fans (Gorgnnia flabellum) the dark horny flexible stem, is seen to be covered in many parts with a brittle crust, often brightly colored, which can be scaled off and crumbled to powder. Between the two, in the living state, the fleshy coat existed; the inner part of it, being in contact with the exterior of the horny stem, which was then soft, and scarcely distinct from it, while the exterior part was consolidated by the earthy matter into the firm integument. The animals (in Gorgonia) may be scattered irregularly over the whole surface, or they may range in series or bands, on opposite sides only, of the stems and branches. The 
cortex consists of the layer of Polypes, with a variable proportion of calcareous matter, secreted within their texture; it is at times, like paper in thinness, and in other species, is thick and spongy." In the Gorgonia verrucosa, Cavolini states that the ova, which are developed in an ovarium, situated at the base of each polype, doubtless in the meso-gastric folds, are discharged by eight small pores, situated at the bases of the eight tentacles. The ova escape as ciliated 'planuloe' (planus flat, applied to flat ciliated forms of larva,) of an ovoid form, which emerge from the ovarian pores with their small end foremost. In the month of June, a Gorgonia, six inches in height, discharged ninety such larva in the space of an hour. They first rose spirally towards the surface of the water, then swam horizontally. They have the same property as the ciliated planula of the marine.Hydrozoa, of changing their form, by the contraction of their tissue, a property which the ciliated zoopores of sponges and algre do not possess. When the larva of the Gorgonia rested, they attached themselves to the sides of the vessel, containing them, by their larger end. The hues of Gorgonidæ are gorgeous and varied. The brightest red, crimson, purple, orange, and yellow are common, besides white, brown, and black, and the polypes add other and more delicate tints, when their star-like flowers are in full blossom.

\section{PEN N A T U L ID A.}

SUB-order Alcyonaria, unattached, either free, or with their base burned. These zoophytes are either flat plates, simple stems, or plume-like fronds. The polypes occur on one or both sides of the stem or branches, and, in a single genus, (Umbellularia) form a cluster at the extremity. The base of the zonphyte is often somewhat enlarged, and some species, by means of it, are planted in the mud. The greater part of them secrete a slender, solid axis, along the main stem or mid-rib of the frond, 
which is either cartilaginous or calcareous. (The polypi have the general characteristics of Alcyonia).

The Renilla Americana, resembles a thick reniform leaf, with a short pedicle. In the contracted state, the upper surface is sprinkled with minute white dots and larger sub-stellate spots, about three-fourths of a line in diameter. The former, under the microscope, consist of eight points, and are probably young budding polypes; the larger are adult polypes and are about a line apart. The general surface is fitted with minute calcareous spicula, seen only under a magnifier. Below, the zoophyte is venously striate, and the caudal appendage is longitudinally sulcate and transversely fine rugate.

\section{A C T IN I A D E.-(Sea Anemones.)}

"A SEA anemone, is a radiate animal, or actiniform polype. Character.-Animal single, fleshy, elongate or conical, capable of extending or contracting itself, fixed by its base, but with the power of locomotion. Mouth, in the middle of the upper disc, very dilatable, surrounded by one or more rows of tentacula. Oviparous and viviparous ; marine." -A sea anemone is a helianthoid or sun-flower shaped polype. "This family of polypes, from the fibrous character which the substance of their body assumes, have been named by zoologists, 'Fleshy Polypes.' The body of an Actinia, when moderately expanded, is a fleshy cylinder, attached by one extremity to a rock or some other sub-marine support ; whilst the opposite end is surmounted by numerous tentacula, arranged in several rows around the oval aperture, when these tentacula are expanded, they give the animal the appearance of a flower, a resemblance which is rendered more striking by the beautiful colors which they not unfrequently assume; and hence, in all countries, they have been looked upon by the uninformed as sea-flowers, and distinguished by names indicative of the fancied resemblance. Their animal nature is soon, however, rendered evident, by a little attention, to their habits. When expanded at the bottom of the shallow pools of salt water left $b y$ the retreating tide, they are seen to manifest 
a degree of sensibility, and power of spontaneous movement, which we should little anticipate from their general aspect. A cloud veiling the sun will cause their tentacles to fold, as though apprehensive of danger from the passing shadows; contact, however slight, will make them shrink from the touch; and if radely assailed, they completely contract their bodies, so as to take the appearance of a hard coriaceous mass, hardly distinguishable from the substance to which they are attached.

"The Actiniæ, like the Hydræ, possess the power of changing their position. They often elongate their bodies, and remaining fixed by the base, stretch from side to side, as if seeking food at a distance; they can even change their place, by gliding upon the dise which supports them, or detaching themselves entirely, and swelling themselves with water, they become of nearly the same specific gravity as the element which they inhabit, and the least agitation is sufficient to drive them elsewhere: when they wish to fix themselves they expel the water from their distended body, and sinking to the bottom, attach themselves again by the dise at their base, which forms a powerful sucker. From this sketch of the outward form of these polypes, we will be prepared to examine their internal economy, and the more minute details of their structure. On examining attentively the external structure of the body, it is seen to be covered with a thick mucous layer, resembling a soft epidermis, which extending over the tentacula and the fold around the aperture of the mouth, is found to coat the surface of the stomach itself; this epidermic secretion forms, in fact, a deciduous tunic which the creature can throw off at intervals. On removing this, the walls of the body are seen to be made up of fasciculi of muscular fibre, some running perpendicularly upwards towards the tentacula, and others which cross the former at right angles, passing transversely around the body; the meshes formed by this interlacement are occupied by a multitude of granules, apparently of a glandular nature, which give the integument a tuberculated aspect : these granules are not seen upon the sucking disc at the base.

"The tentacula are hollow tubes, composed of fibres of the same description. The stomach is a delicate folded membrane, form- 
ing a simple bag within the body. It seems to be merely an extension of the external tegument, somewhat modified in texture. It is closed inferiorly, the same orifice serving both for the introduction of food, and the expulsion of effete, or indigestible matter. On making a section of the animal, the arrangement of these parts is distinctly seen-the muscular integument, the tentacula, formed by the same fibrous membrane-and the stomach, which is apparently derived from it. Between the digestive sack, and the fibrous exterior of the body, is a considerable space, divided by a great number of perpendicular fibrous partitions, into numerous compartments, which, however, freely communicate with each other, and likewise with the interior of the tentacula. Every tentacle is perforated, at its extremity by a minute aperture, through which the sea-water is freely admitted into these compartments, so as to bathe the interior of the body; and when, from alarm, the animal contracts itself, the water, so admitted, is forcibly expelled in fine jets through the holes by which it entered. There can be no doubt that the surrounding fluid, thus copiously taken into the body, is the medium by which its respiration is effected; and every one who has been in the habit of keeping Actinioe in glass vessels for the purpose of watching their proceedings, must have noticed, that as the fluid, in which they are confined, becomes less respirable, from the deficiency of air, the quantity taken into the body is enormous, stretching the animal until it rather resembles an inflated bladder than its original shape. It is in the compartments, which are thus at the will of the creature distended with water, that we find the convoluted and frilled bands which constitute the ovaries, covered with cilia. The germs which are there developed find their way out through a duct, which opens at one angle of the mouth. The eggs found in the ovaria, are round and of a yellowish color, resembling minute grains of sand. The ovigerous membrane which secretes these eggs, is, through its whole extent, bathed with water, admitted into the compartments in which it is lodged, a circumstance which provides for the respiration of the ova during their development. It is a pleasing sight, and one, by no means uncommon, to see five, ten, or twenty young, of various sizes, but perfect in form, expelled from the 
duct and dispersed around, where they soon attach themselves, and constitute a colony around their parent. The young while in the body of the parent, are not unfrequently found in the hollow tentacles which communicate freely with the interseptal chambers; and Sir John Dalyell thought this was their normal position. He says 'in the course of six years, a specimen preserved by the author produced above two hundred and seventysix young; some pale and like mere specks, with only eight tentacula ; others florid and with twenty. They are frequently disgorged along with the half digested food ; thirty-eight appearing thus at a single litter.' 'The abbe Dicquemare relates several curious experiments on the multiplication of these animals by mechanical division. When transversely divided, the upper portion still stretched out its tentacles in search for food, which, when seized, sometimes passed through its mutilated body, but was occasionaly retained and digested. In about two months, tentacles grew from the cut extremity of the other portion, which soon afterwards began to seize prey. By similar sections, he even succeeded in making an animal with a mouth at each end.

"It is in seizing and devouring their prey however, that the habits of the Actinice are best exemplified. They will remain for hours with their arms fully expanded and motionless, waiting for some passing animal which chance may place at their disposal, and when the opportunity arrives, are little inferior to the Hydræ in their voracity or powers of destroying their victims. Their food generally consists of crabs or shell-fish, animals apparently far superior to themselves in strength and activity, but even these are easily overpowered by the sluggish yet persevering grasp of their assailant. No sooner are the tentacles touched by a passing animal, than it is seized and held with unfailing pertinacity: the arms gradually close around it; the mouth placed in the centre of the disc, expands to an extraordinary size; and the creature is soon engulphed in the digestive bag of the Actinix, where the solution of all its soft parts is rapidly effected, and the hard, indigestible remnants speedily cast out at the same orifice. The Actiniæ, although exceedingly voracious, will bear long fasting. They may be preserved alive for a whole 
year, or perhaps even longer, in a vessel of sea-water, without any visible food; but when food is offered, one of them will devour a crab, as large as a hen's egg or two muscles in their shells; in a day or two, the shells are voided through the mouth, perfectly cleared of the soft parts which they contained. The tentacles have the same prehensile power as those of the Hydroe, a power which depends on the presence of projectile barbed weapons, ordinarily coiled in elastic cells. These organs are coiled in inconceivable multitudes imbedded in the tissues of the tentacles, of the lips, of the stomach, of the frilled ovarian bands, and especially, in some species, in long threads which are protruded from pores in the integuments of the body. The structure of these weapons is as follows:-each consists of an oval or elliptical sac of transparent membrane, within which is seen a thread coiled up, and in some instances, an oblong or lozenge-shaped chamber. At the pleasure of the animal, or under the stimulus of pressure, the thread is shot forth from one end of the cell with great force, until it extends to a length of from twice to fifty times that of the cell. When fully extended, it seems that the thread is but a continuation of the cell itself; that when it was dormant, it was turned in; and that in the process of expulsion, every part of its length has actually been turned inside out, like the finger of a glove. Sometimes the thread appears simple, but in those cases, in which a chamber appeared within the cell, it is furnished with an armature of barbed threads, which, after the expulsion, project from the sides of the thread in all directions. The propulsion of the thread is sufficiently forcible to enable it to enter the tissues of other animals, and the barbed structure enables the weapon to retain its hold in the flesh, which facts warrant the presumption that a highly poisonous fluid is at the same time injected, capable of arresting and destroying the animal life. Although the prey of the Actinia usually consists of crustacea, the smaller mollusca and star fishes; it is sometimes of much greater dimensions. Dr. Johnson observes, "I had once brought me a specimen of Actinia crassicornis, that might have been originally, two inches in diameter, and that had somehow contrived to swallow a valve of the great scallop (Peeten maximus) of the size of an ordinary 
saucer. The shell fixed within the stomach was so placed as to divide it completely into two halves, so that the body stretched tensely over, had become thin and flattened like a pancake. All commnnication between the inferior portion of the stomach and the mouth was of course prevented, yet instead of emaciating and dying of an atrophy, the animal had availed itself of what had undoubtedly been a very untoward accident, to increase its enjoyments and its chance of double fare.' A new mouth furnished with two rows of numerous tentacula was opened up on what had been the base and led to the under stomach. The individual had indeed become a sort of Siamese twins, but with greater intimacy and extent in its unions."

Metridium Prætextum, (J. P. Couthony,) exhíbited wholly in the plate, is generally found with its body covered with sand, having its disc expanded on a level with the surface. When molested they entirely conceal themselves beneath the sand. Specimens were obtained off Santa Cruz : also on the north side of the harbor, near Praya Grande. Another allied species was observed by Dr. C. Pickering in the sand among the rocks outside of the harbor.

A CALEPH AE.

"IN the third division of Acalephæ, denominated by Cuvier, 'Acalephes Hydrostatiques,' the body is supported in the water by a very peculiar organ, or set of organs, provided for the purpose. This consists of one or more bladders, capable of being filled with air at the will of the animal, which are appended to the body in various positions, so as to form floats of sufficient buoyancy to sustain the creature upon the surface of the sea, when in a state of distension; but, when partially empty, allowing it to sink, and thus escape the approach of danger." "The most conspicuous, if not the most typical, member of the Physograde order of Acalephr is the Physalia, (known to sailors by the name of the Portuguese man-of-war,) in which all that part answering to the disc in the 'Pulmograde' order, is expanded into a bag, the major part of which is occupied by an air-bladder, whilst the digestive cavity is subdivided amongst a series of appendages attached to one part of the under surface of the bag. 
This part consists of an outer thin and dense membrane, of an inner thicker membrane beset with long cilia, and of an airbladder, which at one point is attached to the above membranes, where there is a small constricted aperture, at least in the outer membrane. This membrane is developed into a kind of crest along its upper part." "The air-bladder is endowed with a considerable power of contraction, and when carefully examined, two orifices are observable, one at each extremity, through which, upon pressure, the contained air readily escapes, a provision for enabling the creature to regulate its specific gravity at pleasure, and, when alarmed, at once to lessen its buoyancy by diminishing the capacity of its swimming-bladder, and to sink into the waves." "The opinion that these animals are able to expel the air from the air-bladder at will, was rendered-doubtful, as a general rule, by Olfers, who could find no opening in the large bladder of Physalia. [Subsequent observations, however, have determined that Physalia is the only one of the Physsophoridre whose bladder does really communicate with the external air. But, though there be no such communication in the rest, Leuckart states that in many of them (and he believes it to be true of all,) the air may be readily caused to pass from the cavity of the bladder into that of the common stem, by the expansion of the upper extremity of which the air-bladder is in all cases surrounded." "Quatrefages has described the action of the sphincter muscle, and the connexion of both bladders with the aperture; he also caused the air contained in the interior bladder to be analyzed, and found that it contained less of oxygen than atmospheric air, by about three per cent.; the animal appeared to be able to expel the air voluntarily at intervals, and to distend the bladder again after a short time; it would therefore seem to be a respiratory organ for the colony. The air-bladder is surrounded on all sides by the external bladder or envelope, which is, in fact, the expanded stem of the colony; with the under surface of this the various appendages are connected, and into its cavity the cavities of them all open more or less directly. The bladder in Physalia did not appear to Quatrefages to be merely a passive organ, for besides the power of emptying and distending it, the animal seemed to be able to direct the fluid contained in the 
cavity of the appendages into this or that bundle of them at will, and so to alter the position of the centre of gravity of the bladder, and by thus bringing different regions of it to the surface, to steer its course.] The appendages are of three kinds: Urticating, digestive, and (probably) generative. The urticating tentacles are the longest; they are hollow, and are provided with muscular fibres, of which the most conspicuous are longitudinal, and serve to retract them. They contain many corpuscles of a reniform shspe, and are richly provided with thread-cells, whose filaments are of the spiral kind. The gastric appendages are shorter and wider, and are provided with stomata, which are applied to the prey seized and benumbed by the tentacles. If the prey be small, it is sucked bodily into the gastric sac; if large, the sac becomes distended with its juices and dissolved parts, the gastric secretion being a very rapid and powerful solvent. The mouth of each sac is wide, with a broad everted lip, armed with a series of 'nettlecells.' The whole gastric appendage is highly contractile, and in constant motion in the living animal. The appendages of the third class are cyathiform."

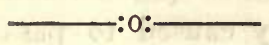

\section{E C H IN O D E R M A T A.-(Asteroidea.)}

"The casual observer who should, for the first time, examine a star-fish, or a sea-urchin, two of the most familiar examples of the Echinodermata met with upon our shores, would indeed find it a difficult task to associate them with any other class, or to imagine the affinities whereby they are related, either to the simpler animals we have already described, or to more perfect forms of existence hereafter to be mentioned. They would seem to stand alone in the creation, without appearing to form any portion of that series of development which we have hitherto been able to trace. But this apparent want of conformity to the general laws of development vanishes on more attentive examination; so that we may not only trace the steps by which every family of this extensive class merges insensibly into another, but perceive that, at the two opposite points of the circle, the Echidermata are intimately in relation with the Polyps on one hand, 
while on the other they as obviously approximate the annulose animals, to which the most perfectly organized amongst them bear a striking resemblance. In Ophiurus, the rays are long and simple, resembling the tails of so many serpents-a circumstance from whence the name of the family is derived. Nevertheless, on each side of every ray we still trace movable lateral spines, which, although but mere rudiments of what may be seen in Comatula, may still assist in locomotion, or perhaps may contribute to retain the prey more firmly when seized by the arms. The rays themselves are composed of many pieces curiously imbricated and joined together by ligaments, so that they are, from their length and tenuity, extremely flexible in all directions, and serve not only for legs adapted to crawl upon the ground, but are occasionally serviceable as fins, able to support the animal in the water for a short distance by a kind of undulatory movement. The body, or central disc, is beautifully constructed, being made up of innumerable pieces accurately fitted together. The mouth occupies the centre of the ventral surface, and is surrounded by radiating furrows, in which are seen minute apertures that give passage to a set of remarkable prehensile organs; these are calculated to act as suckers, and so disposed as either to fix the body of the animal, or to retain food during the process of deglutition. In Ophiurus we have just mentioned the existence of protrusible suckers around the opening of the mouth, well adapted, from their position, to take firm hold of food seized by the animal; and it is by increasing the number of such organs that ample compensation is made for the loss of motion in the rays themselves in the star-fishes. On examining the lower surface of an Asterias, even in those forms which most approximate a right-lined pentagon in their marginal contour, the number of rays will still be found to be distinctly indicated by as many furrows radiating from the mouth, and indicating the centre of each division of the body. These ambulacral furrows, as they are termed, exhibit, when examined in a dried specimen, innumerable orifices arranged in parallel rows, through each of which, when alive, the animal could protrude a prehensile sucker, capable of being securely attached to any smooth surface. No verbal description can at all do justice to this wonderful mechanism, 
even leaving out of the question the means by which each individual sucker is wielded; but let any of our readers, when opportunity offers, pick up from the beach any of these animals, the common star-fish of our coast, which, as it lies upon the sand left by the retiring waves, appears so incapable of movement, so utterly helpless and inanimate; let him place it in a large glass jar filled with its native element, and watch the admirable spectacle which it then presents: Slowly he perceives its rays expand to their full stretch; hundreds of feet are gradually protruded through the ambulacral apertures, and each, apparently possessed of independent action, fixes itself to the sides of the vessel as the animal begins its march. The numerous suckers are soon all employed, fixing and detaching themselves alternately, some remaining firmly adherent, while others change their position; and thus, by an equable gliding movement, the star-fish climbs the sides of the glass in which it is confined, or the perpendicular surface of the submarine rock. But it is not only as agents in locomotion that the ambulacral suckers are used; helpless as these creatures appear to be, they are among the most formidable tyrants of the deep, as will be readily admitted by any one who watches them in the act of devouring prey. When seizing its food, the rays of the Asterias are bent towards the ventral aspect, so as to form a kind of cup, in the centre of which is the opening of the mouth; the cup thus formed will, to a certain extent, lay hold of a passing victim; but, without other means of securing it, the grasp would scarcely be very formidable to animals possessed of any strength; armed, however, as the rays have been found to be, with hundreds of tenaceous suckers, escape is almost impossible, for prey once seized is secured by every part of its surface, and, in spite of its utmost efforts, is speedily dragged into the mouth, and engulphed in the capacious stomach, where its soft parts are soon dissolved.

"On examining a living Asterias, the outer covering of its body is found to be composed of a dense coriaceous substance, in which numerous calcareous pieces are apparently imbedded. The coriaceous integument is generally colored externally with lively tints, and is evidently possessed of considerable irritability, as it readily shrinks under the knife, or upon the application of various 
stimuli. When cut into, it has a semi-cartilaginous hardness, and fibrous bands, almost resembling tendon in their aspect, may be seen to radiate from the centre of the body towards the extremities of the rays. There is no doubt that the movements of the rays are effected by the contractions of this fibrous membrane. The skeleton, or calcareous framework imbedded in the skin of the Asteridze, is by no means the least remarkable part of their structure. This consists of several hundred pieces, variously disposed, and for the most part fitted togetherwith great accuracy; being either firmly soldered to each other, as we have seen them to be in the formation of the calcareous box that constitutes the central portion of Ophiurus, or united by ligaments, so as to allow of a considerable degree of motion to take place between them, as in the rays of Ophiurus, and other asteroid forms." "The star-fishes, grossly considered, might be regarded as mere walking stomachs; and the office assigned to them in the economy of nature, that of devouring all sorts of garbage and offal which would otherwise accumulate upon our shores. But their diet is by no means exclusively limited to such materials, since crustaceans, shell-fish of various kiads, and even small fishes, easily fall victims to their voracity. Neither is the size of the prey upon which they feed so diminutive as we might suppose, from a mere inspection of the orifice representing the mouth; for this is not only extremely dilatable, but, as we have found to be the case in the Actiniæ, the stomach is occasionally partially inverted, in order more completely to embrace substances about to be devoured. Shell-fishes are frequently swallowed whole, and a living specimen of Chama antiquata, Lin., has been taken from the digestive cavity of an Asterias, in an entire state. It appears, moreover, that it is not necessary for testaceous Mollusca to be absolutely swallowed, shell and all, to enable the Asteridæ to obtain possession of the inclosed animal, as they would seem to have the power of attacking large oysters, to which they are generally believed to be peculiarly destructive, and of eating them out of their shells. The ancients believed that, in order to accomplish this, the star-fish, on finding an oyster partially open, cunningly inserted one of its rays between the valves, and thus, gradually insinuating itself, destroyed its victim. Modern ob- 
servations do not, as far as we are aware, fully bear out the above opinion of our ancestors as to the mode in which starfishes attack oysters, although the destruction which they cause is pretty generally acknowledged.

"The observations recorded by M. Eudes Deslongchamps upon this subject are, however, exceedingly curious. As the waves had receded from the shore, so as to leave only one or two inches of water upon the sand, he saw numbers of Asterias rubens rolling in bunches, five or six being fastened together into a sort of ball by the interlacement of their rays. He examined a great number of such balls, and constantly found in the centre a Bivalve Molluse, (Mactra Stultorum, Lin.) of an inch and $\mathbf{a}$ half in length. The valves were invariably opened to the extent of two or three lines, and the star-fishes were always ranged with their mouths in contact with the edges of the valves. On detaching them from the shell which they thus imprisoned, he found that they had introduced between the valves large rounded vesicles with very thin walls, and filled with a transparent fluid. Each Asterias had five of these vesicles ranged around its mouth, but they were of very unequal size; generally there were two larger than the rest, equal in size to large filberts, while the other three were not bigger than small peas. These vesicles appeared to be attached to the Asterias by short pedicles, and at the end of each was a round open aperture, through which the fluid contained in the vesicle flowed out drop by drop. No sooner was the animal detached from the shell that it was thus sucking, than the vessels collapsed, and became no longer distinguishable. The Mactra were all found to be more or less devoured, some having only their adductor muscles left; but, however little they had been injured, all had lost the power of closing their valves and were apparently dead; nevertheless there was nothing to lead to the supposition that only dead shell fishes were attacked, so that it is difficult to imagine how the delicate vesicles above described escaped injury from the closing of the valves. M. Deslongchamps thinks that probably the Asterias pours into the shell a torpifying secretion, and thus ensures the death of its victim." "The Asterias possesses no organs specially appropriated to respiration; but the sea water being freely admit- 
ted into the general cavity of the body through a set of minute membranous tubes seen upon the exterior of the animal, bathes all the viscera, and consequently ensures a complete exposure of the circulating fluids to the influence of oxygen,- - the whole peritoneal surface performing the office of a respiratory apparatus.

"The nervous apparatus of the Asteridæ, consists of a simple circular cord, which runs around the mouth of the animal; from this ring, three delicate filaments are given off opposite to each ray, one of which according to Tiedemann, runs along the centre of the ambulaceal grove upon the under surface of the body, and gives minute twigs to the locomotive suckers placed on each side of its course; the other two filaments, pass into the visceral cavity, and are probably distributed to the internal organs. There are no ganglia developed on any part of this nervous apparatus; or at least, if, as some writers assert, ganglionic enlargements are visible at the points whence the radiating nerves are given off, they are so extremely minute as not in any degree to merit the appellation of nervous centres." "The general sense of touch in the Asteridæ is extremely delicate, serving not only to enable them to seize and secure prey, but even to recognise its presence at some little distance, and thus direct these animals to their food. Any person who has been in the habit of fishing with a line in the shallow bays frequented by star-fishes, and observed how frequently a bait is taken and devoured by them, will be disposed to admit this; yet to what are we to attribute this power of perceiving external objects? It would seem most probably due to some modification of the general sensibility of the body, allowing of the perception of impressions in some degree allied to the sense of smell in higher animals, and related in the character to the kind of sensation by which we have already seen the Actiniæe and other polyps able to appreciate the presence of light, although absolutely deprived of visual organs." 


\section{ECHINOIDEA.}

"THe Echini, hotwever they may appear to differ in outward form from the Asteridæ, will be found to present so many points of resemblance in their general structure, that the account we have given above, of the organization of the last mentioned family, will throw considerable light upon the still more elaborately constructed animals which now present themselves to our notice."

"The Echini may be found in abundance upon our coasts, inhabiting the sea, not far from the shore, or lurking among rocks, where they obtain the means of sustenance. Their shape is more or less completely globular, and their whole surface covered with strong spines, on which they roll themselves from place to place, moving them all as though they were stiff legs; but if they wish to hide themselves from observation, or perceive they are in danger of being left upon the shore by the retreating tide, these numerous spines perform the part of rakes, and scraping up the sand, soon makes a kind of grave into which the creature sinks, till it is covered over, securing for itself, by this proceeding, safety from external violence and also water to respire until the tide comes back.

"Such power of walking in an animal that is enclosed on all sides in a shelly box, seems in itself sufficiently surprising, but when we learn that it can climb the cliff in search of food, and even make its way, while pendant from the roof of rocky caverns, we scarcely can conceive the possibility of its performing feats so difficult, and eagerly inquire what means have been provided for the purpose.

"Whoever takes the trouble to observe the Echinus while alive, confined in fresh sea water, or at large upon its native rock, will not be long in doubt upon this point. Protruding from the shell, and reaching past the points of even the longest spines, appear innumerable suckers evidently similar in their construction, and in function too, to those of the Asteridoe. These are applied in turn to the smooth inner surface of the glass, or to the stone on which the creature climbs, and by the aid of this elaborate 
mechanism the Echinus glides along to browse the corralines, and other Zoophytes, which clothe the rocky reef or sea-girt precipice. The creature's mouth is carried next the ground; it is a circular orifice, surrounded with a fleshy ring, through which protrude five sharp crystalline teeth, whose points all meeting in the centre serve to nibble off the substances employed as nutriment, and thus, without apparent instruments of sense, such as belong to higher animals, and unpossessed of limbs except its spines and suckers, the sea urchin marches on with ease, in situations where, apparently, no footing could be found, and lives a life of indolent security, encased in solid armor and beset with spines, compared with which, the bristles of the hedge-hog are a poor protection. Such being the general habits of the Echinidoe, our next inquiries must relate to their construction, and perhaps we are already prepared to expect that this must offer many features worthy of remark.

"The shell, or dense calcareous crust, that seems to enclose the animal, is really placed internally, for although it contains the viscera appointed for nutrition, all the living flesh, the real substance of the creature is external to it. Let this fact be well remembered if we would appreciate the analogies which still ally those globe-like beings to the star-fishes, and through them to the polyps.

"The shell, in the fresh animal, is covered over with a thin fleshy skin filled with calcareous points. This skin is fibrous and contractile, being, in truth, the representative of the soft fleshy covering that encases all the branches of an Enorinite, and which in Asterias moves the rays and spines. It is in fact the animal itself; it forms the shell within and likewise wields the external organs, the stiff prickles, when employed as instruments of locomotion. Though more distinctly muscular than in inferior zoophytes, and consequently capable of contracting more energetically, it contains the power of separating earthy matter from the sea wherewith it moulds the shell that gives it shape, and also constructs the countless spines that stud the outer surface of the body, all of which are built by slow precipitation of calcareous particles secreted by the living skin itself. Immediately beneath the living tegument is placed the shell, itself a 
structure, perhaps the most elaborately framed of any we have had occasion to allude to: a piece of workmanship so exquisite, so far beyond all human art, so visibly demonstrating sovereign skill and boundless wisdom, that a sense creeps over the mind as we proceed with all humility to contemplate so great a miracle. And here we may observe that such examples of contrivance and of obvious intention as are frequently displayed in what may be termed the ruder mechanism of nature, often come with greater emphasis upon the heart, than all the more mysterious wonders that abound in natural science.

"The physiologist perceives at every step, proofs of design which baffle human comprehension, but the ideas they raise are vague and undefined, and so, of course, the application too is indistinct; but when we can, from first to last, perceive the end in view, and understand the means of its accomplishment, the mind is satisfied, and owns at once how great the foresight and how grand the power of the Supreme Designer.

"The crust of the Echinus, when denuded of its spines, and stripped of its external coverings, would seem to be an ordinary shell, having its outer surface covered over with polished tubercles, regularly arranged. Of these the largest are disposed in lines that pass from pole to pole of the round box, like lines of longitude upon the globe of the geographer.

"Intermixed among the larger tubercles are seen innumerable smaller eminences of similar construction, but dispersed with less precise arrangement, upon all of which, when in a living state, spines were attached in corresponding number. Moreover, placed at intervals between the spine-crowned tubercles are ten broad bands, disposed in pairs, all pierced with countless holes; these too extend from pole to pole of the round box, and through them, during life, the locomotive suckers passed, already noticed as being used for climbing rocks or for attachment to some foreign body. On cutting through the shell, so as to see its inner surface, we perceive, to our surprise, that far from being, as it appears externally, a simple shelly exudation moulded to the form of the Echinus like the shells of lobsters or mollusca, it is a very complex fabric built with most consummate art, consisting of some thousand pieces varying in size, but shaped with 
mathematical precision, and conjured with so much accuracy, that the eye can but with difficulty trace the line of union. Tell a human artisan, however versed in geometrical proportions, to cut out a thousand plates, polygonal in form, and fit them to each other, leaving not the slightest space between their margins any where, so that the whole shall form a hollow sphere of certain given proportions, how would he succeed? Doubtless he would pronounce the problem quite impracticable. But in the shell before us, that is what nature has achieved most perfectly. First, we observe five double rows of oblong plates, pentagonal in form, which on their outer sides present the spine-supporting

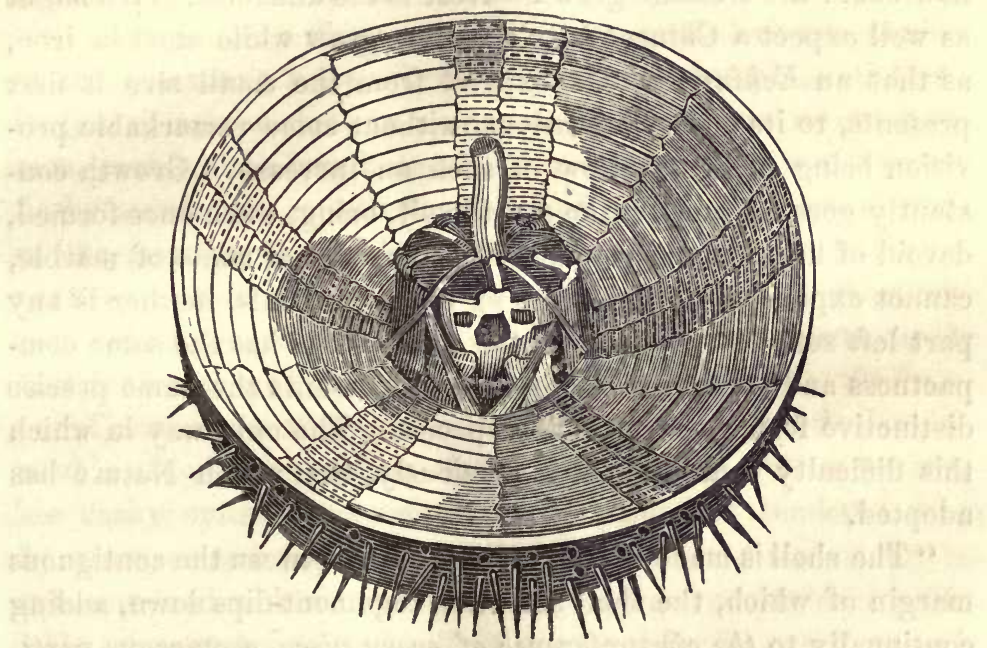

tubercles. On either side are found innumerable pieces of a smaller size, but equally exact in shape, through which are bored the perforations for the ambulacral feet, and these again are separated from another row of perforated plates by other intermediate pieces having spines affixed externally. These plates are mostly pentagons in form, with sides of various lengths, but all combined, fit each other so closely, that their combination seems to form one solid, compact shell.

"We shall not stop to count the number of the plates comprised in every series, or to calculate how many perforations are provided for the feet. Let the reader try to number them when 
opportunity occurs, though here, numbers are of little consequence. Let us rather ask why Nature in this case has chosen to work by laws so complex, when we might suppose a simpler fabrie might have done as well? why frame a shell composed of thousands of small portions thus connected, when even in higher animals all this elaborate device can be dispensed with? A little thought will convince us that, even here as elsewhere, Nature has employed no useless superfluity of structure. To case the animal in stone, would have been a simple process; as we have already seen that almost all the zoophytes secrete calcareous matter in abundance; but, when thus closed up in a stony shell, how could the creature grow? Here is the difficulty. We might as well expect a Chinese lady's foot to grow while shod in iron, as that an Echinus should expand from the small size it first presents, to its adult dimensions, without some remarkable provision being made to allow of such an increase. Growth constantly goes on, and yet the crust itself, being, when once formed, devoid of life, and as incapable of growing as if made of marble, cannot expand as do the bones of higher animals, neither is any part left soft, but at all ages, the whole shell has the same compactness and solidity throughout, and presents the same precise distinctive form peculiar to the species. The only way in which this difficulty could be met is, obviously, that which Nature has adopted.

"The shell is made of numerous pieces, between the contiguous margin of which, the shell secreting tegument dips down, adding continually to the circumference of every piece, cretaceous particles, layer after layer, by which the superficial size of each progressively increases, whilst its form remains unchanged. The - thousand pieces that compose the shell, thus simultaneously become enlarged, and as they never change their figure or the relative proportions that they bear to all the rest, the entire shell expands without the slightest deviation from the given form, till it attains the limit of its growth.

"Examine well the spines. The base of every spine presents a smooth concavity or socket, which exactly fits one of the rounded tubercles already pointed out, upon the outer surface of the shell, and forms a perfect joint. No matter how minute the 
spines, be they as thin and delicate as the fine pile of velvet, such as exist in the Clypeaster and in other flattened genera, or large and club-shaped, as in Cidarites, the joint is equally complete and movable in all required directions. In the last mentioned race, indeed, we see additional provisions made to give secure attachment, the centre of each tubercle being furnished with a little pit, from which arises a strong ligament that is implanted in the base of the appended spine to obviate all chance of dislocation.

"To understand the mode in which the spines are all produced, and fixed upon the body of the Echinus, we must again refer to the soft tegument whereby the numerous pieces of the shell are all secreted. The skin, which is, in fact, the living substance of the creature's body, likewise constructs the spines, and if a section of one of these is prepared, taken from a recent specimen, each will be found, encrusted over with a layer of this soft fleshy membrane, as were the stems of corals, or Gorgonice; and in like manner, the investing film is able to secrete cretaceous particles, which are arranged, stratum investing stratum, with such art and regularity, that few more beauteous objects can be found, than one of these neglected spines."

"The suckers of the Echini, in all essential particulars, resemble exactly those of an Asterias, consisting of long projectible fleshy cylinders, which are protruded and rendered tense by water, or some other fluid injected into them, from an apparatus contained within the body. The degree to which the protusible tube can be exerted will of course differ in every genus in proportion to the length of the locomotive spines, it being absolutely necessary, that, however long the latter organs may be, the prehensile portion of the sucker shall be able to reach beyond them; so that in the long spined genera, of which, in warm climates, some are found having spines several inches in length, the tubes, with their appended adhesive discs, resemble little cables thrown out to a distance, for the animals, in order to secure an anchorage, or ropes whereby to hoist themselves from ledge to ledge, of the steep rock, on which their food is found.

"These suckers that surround the mouth perform, besides, 
another duty, and may be compared to fishing lines, ready to seize upon such prey as comes within their reach and drag it to the mouth to be devoured."

\section{H OLOTH U R O IDEA.}

"A Holothuria may be regarded in one light as a soft SeaUrchin, in another as a radiated animal, approximating the Annalides." "In common language they are generally known by the appellation of 'Sea cucumbers;' and in fact, to a casual observer, the resemblance which they bear to those productions of the regetable kingdom, both in shape and general appearance, is sufficiently striking. The integument which covers, or rather forms the body, is entirely destitute of those calcareous pieces which encase the Echini and Star-fishes; but appears to consist of a dense fibrous cutis of considerable thickness, covered externally with a thin epidermic layer. Beneath the cutis is another tunic composed of strata of tendinous fibres crossing each other in the midst of a tissue of a semi-cartilaginous nature, which is capable of very great distention and contraction, and serves by its elasticity to retain the shape of the body. Within this dense covering are scen muscular bands running in different directions, which by their contraction give rise to the various movements of the creature. But although the calcareous shell of the Echinus is thus totally lost, the locomotive suckers or feet already described are still the principal agent employed in progression. In many species, these organs are distributed over the whole surface of the animal, and are protruded through countless minute orifices which perforate the integument. In other cases, they are arranged in five series, resembling the ambulacra of an Echinus; and in some instances they are only found upon the middle of the ventral surface of the body, that forms a flattened disc upon which the animal creeps somewhat in the manner of a snail. The ambulacral feet themselves precisely resemble in all the details of their structure those of the Asterias, and their pro- 
trusion and retraction are effected in the same manner. The mouth is a round aperture, as wide as a goose-quill, placed in the centre of a raised ring at the anterior extremity of the body. Around the oral orifice is placed a circle of tentacula, which are apparently extremely sensible, and serve perhaps not only as instruments of touch, but as prehensile organs used for the capture of prey, or for assisting in deglutition."

"Sir John Graham Dalyell stated in $\mathbf{1 8 4 0}$ that he had observed the Holothuriæ lose the tentacula, with the cylinder (dental apparatus), mouth, oesophagus, lower intestinal parts, and the ovarium, separating from within and leaving the body an empty sac behind. Yet it does not perish. In three or four months all the lost parts are regenerated, and a new funnel, composed of new branches as long as the long body of the animal, begins to exhibit the same peculiarities as the old one, though longer time be required to attain perfection. Other species of the Holothuria divide spontaneously through the middle into two or more parts, all becoming ultimately perfect by the development of new organs. Yet the anatomical structure of the whole genus is so complex as to defy the skill of anatomists in discovering the proper functions of some of the parts. A single Holothuria has produced 5000 ova in the course of a night. Of one genus, the Trepang, many species are eaten. In Mr. F. D. Bennett's interesting 'Account of a Whaling Voyage round the Globe,' we are told that there are two kinds of Trepang abundant on the rocks at Raiatia, and they are very indolent animals. 'When handled,' says Mr. Bennett, 'the Trepang contracts its body in a longitudinal direction, and should its tentacles be expanded they are instantly concealed; but no noise or agitation of the surrounding water will excite these symptoms of alarm, or cause any attempt to escape. They usually lie exposed in the shallow waters, though we have very often seen them buried in beds of coral sand, their plumy tentacles being alone exposed, and floating in the water above, apparently as a lure for prey. Some may also be observed lying on the rocks, their bodies completely encrusted with coral sand, which may either have been accumulated by a previous burrowing, or thus used as a disguise. It would appear to be partly the instinct of the animal to take its 
prey in ambush; but what that prey is, as well as the entire economy of these Moluscs, remains a perplexing mystery. Their intestines invariably contain many hard and solid masses of madreporic rock or tree-coral, some of them more than an inch in length, and all moulded as pellets to the calibre of the intestinal canal. It is difficult to say how these stony bodies have been obtained by the Trepang, though it is easy to conceive that they may be rendered serviceable as nutriment by the assimilation of the animal matter they contain. It is this animal which the Malays of the Oriental Isles seek so diligently, for the supply of the China market, where it obtains a good price when well preserved. It is employed by the Chinese in the preparation of nutritious soups, in common with an esculent sea-weed, Shark's fins, edible bird's nests, and other materials, affording much jelly.' Jaeger says the intestines are extracted, the animal then boiled in sea-water, and dried in smoke."

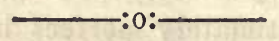

\section{CRUSTA CEA.}

"THE Crustacea pre-eminently make the waters their home; they are the aquatic division of that mighty host of living things, that range under the title of ARticulata. In most respects, CRUSTACEA are so much like insects, that the older naturalists, and the illustrious Linnæus among the number, arranged them under the great class Insecta. They have, however, a greater number of limbs; the full provision being five pairs of true feet, and three pairs of organs, which are called foot-jaws. Besides these, a great number of the species have five or six pairs of jointed limbs attached to the underside of the abdomen, which are generally used for progression, and are called false feet.Their mouth is furnished with three pairs of jaws and two pairs of antennæ. It must be borne in mind, however, that the total complement of these members is not found present in every species, some of them being wanting in certain extensive groups.The researches of a naturalist who has paid much attention to this class, Mr. Spence Bate, have shed a flood of interesting light on the office of the organs last-named. Any one may easily 
identify them in the Lobster or Prawn. Take the latter. On each side of the long sword-like and spiny beak that projects above the head, there is an organ consisting of three stout joints, at the tip of which are three threads, of which two are of great length, and formed of numberless rings, and the third is short. These organs, then, constitute the inner pair of antennæ.Below these there is a pair somewhat similar, but they consist each of five joints, and one long thread with a large flat plate on each side. These are the outer antennæ. The former are the organs of hearing, the latter those of smelling. In the living animal, the inner antennæ are always carried in an elevated posture, and are continually flirted to and fro with a rapid jerking motion that is very peculiar, striking the water every instant. It is very conspicuous in the Crabs, from the shortness of the organs in question. To help the perceptions of the animal, the manyjointed filament which strikes the water, is fringed with hairs of great delicacy standing out at right angles to the stalk, so that the slightest vibrations cannot fail to be conveyed to the sensorium. This may be called the outer ear; but in the interior of the basal joint, which is large and swollen, there is a cochlea, or inner ear, having calcareous walls of delicate texture, to the centre of which passes the auditory nerve. The outer antennæ differ greatly from the inner in their internal structure, though they resemble them so much in form. In the Crabs, the basal joints form a sort of box or compact mass, with an orifice on the side next the mouth, closed or opened at pleasure by means of a little door with a hinge, on the interior side of which a long bony lever is fastened with the necessary muscles attached to it. In the Lobster and Prawn the door is wanting, but the orifice is protected by a thin membrane; and in some of the lower forms it is placed at the end of a strong spine or projection. In all cases, however, the orifice ' is so situated that it is impossible for any food to be conveyed into the mouth without passing under this organ; and of this the animal has the power to judge its suitability for food by raising the operculum (or door) at will, and exposing to it the hidden organ-the olfactory.'

"'The 'crust,' or skin which envelopes the body, in these animals, differs from that of INSECTS, inasmuch as it generally 
contains a considerable portion of carbonate of lime. In many of the smaller forms, as in the Shrimps and Prawns, it takes the consistence of thin transparent horn; but in the larger, as in Lobsters and Crabs, it acquires a great density, is perfectly opaque, and of the hardness of true shell or even of stone. In the tips of the stout claws of the Crab, we see it at its maximum of induration.

"The periodic casting of the skin is a needful provision for growth in these animals, as in Insects; in them it is confined to the caterpillar state, in which alone growth takes place; but here it prevails, because growth is continued long after the perfect form is attained. The rigidity of the encasing armor forbids the possibility of increase in its capacity. The growth, therefore, is periodic. At certain intervals the hard crust is thrown off in several pieces, a new crust having been prepared beneath, which is at first soft, flexible, and expansible. The body, now freed, instantly enlarges in all directions, and, in a few minutes, has attained the full extent of growth needed. The crust at once hardens, and in a brief space becomes as inflexible as was its predecessor, admitting no further enlargement either of its own surface or of the contained organs. The animal usually undergoes this process in the most retired situation it can find, instinctively conscious of its unprotected position when soft, and apparently feeling sick and feeble.

"Another interesting circumstance in the economy of this class, is the power of renewing injured or lost limbs. If one of the joints of a Crab's legs be wounded, it would bleed to death but for this provision. The animal, however, stiffens the hurt limb, and suddenly throws it off, the separation invariably taking place at the point where the second joint is united with the first. A small gland is placed here, according to Mr. H. Goodsir, which supplies material for future legs as required. 'When the limb is thrown off, the blood-vessels and nerve retract, thus leaving a small cavity in the new-made surface. It is from this cavity that the germ of the future leg springs. A scar forms over the raw surface caused by the separation, which afterwards forms a sheath for the young leg.' 'As the growth advances, the shape of the new member becomes apparent, and constrictions appear, indi- 
cating the position of the articulation; but the whole remains unprotected by any hard covering until the next change of shell, after which it appears in a proper case, being, however, still considerably smaller than the corresponding claw on the opposite side of the body, although equally perfect in all its points."

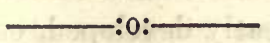

\section{I R R H O P O D A.}

"HOWEVER distinct in outward appearance, and even in their internal economy, the creatures composing the primary divisions of animated nature may seem to be when superficially examined, closer investigation invariably reveals to the zoologist gradations of structure connecting most dissimilar types of organization, and leading so insensibly from one to another, that the precise boundary-line which separates them is not always easily defined. The Cirrhopoda, indeed, present a strange combination of articulated limbs, united with many of the external characters of a Mollusk, as will be at once evident from the examination of any species of Barnacle, whether Sesile or pedunculated." "At first sight no two objects can well be more unlike than a Barnacle and a Shrimp. The former is inclosed in a true shell composed of many pieces united either by shelly matter or by cartilage, which allow of the protrusion and retraction of a hand of fine hairy filaments, the whole permanently affixed to foreign objects either by a thick, flexible stalk, or by a broad immovable base. The older naturalists associated these animals with the shell bearing MoLLUSCA, calling them multivalves, and even up to very recent times they have been considered as equally allied to the sub-kingdom just named and to that in which they occur here. Mr. Charles Darwin, however, in his admirable Monograph, has fully demonstrated the close affinity which subsists between them and the Crustacea, of which he, indeed, considers them only a sub-division. I prefer, however, to treat them as a class by themselves, believing that the diversity between the groups is quite as great as that which subsists between the Crustacea and the Arachidid, or between the Arachinida and the Insecta. The Barnacle begins life in a form exactly like that of a young Entomostracous Crus- 
taceau, with a broad carapace, a single eye, two pairs of antennx, three pairs of jointed, branched, and well-bristled legs, and a forked tail. It casts off its skin twice, undergoing, especially at : the second month, a considerable change of figure. At the third month it has assumed almost the form of a Cypris or Cythere, being inclosed in a bivalve shell, in which the front of the head with the antennæ is greatly developed, equalling in bulk all the rest of the body. The single eye has become two, which are very large, and attached to the outer arms of two bent processes like the letters $U \cup$, which are seen within the thorax.

"In this stage the little animal searches about for some suitable spot for permanent residence; a ship's bottom, a piece of floating timber, the back of a whale or turtle, or the solid rock. When its selection is made, the two antennæ, which project from the shell, pour out a glutinous gum or cement, which hardens in water, and firmly attaches them. Henceforth, the animal is a fixture, glued by the front of its head to its support. Another moult now takes place; the bivalve shell is thrown off, with the great eyes, and their $U$-like processes, and the little Cirriped is seen in its true form. It is now in effect a Stomapod Crustacean, attached by its antennæ, the head greatly lengthened (in Lepas, \&c.), the carapace composed of several pieces (valves), the legs modified into cirri, and made to execute their grasping movements backwards instead of forwards, and the whole abdomen obliterated, or reduced to an inconspicuous rudiment.

"The sessile or stalkless Barnacles or Acorn-shells (Ballanidæ), appear to differ much in the formation of their shells from the Lepadidr, (stalked,) but the diversity is produced by modification of the same essential valves.

"The food devoured by the Cirrhopoda would seem to consist of various minute animals, such as small Mollusks and microscopic Crustacea, caught in the water around them by a mechanism at once simple and elegant. Any one who watches the movements of a living Cirrhopod will perceive that its arms, with their appended cirrhi, are in perpetual movement, being alternately thrown out and retracted with great rapidity; and that, when fully expanded, the plumose and flexible stems form an exquisitely beautiful apparatus, admirably adapted to entangle 
any nutritious molecules; or minute living creatures, that may happen to be present in the circumscribed space over which this singular casting-net is thrown, and drag them down into the vicinity of the mouth, where, being seized by the jaws, they are - crushed and prepared for digestion. No sense but that of touch is required for the success of this singular mode of fishing; and the delicacy with which the tentacula pereeive the slightest contact of a foreign body, shows that they are eminently sensible to tactile impressions."

\section{LT:-0-:- \\ C ON CHIFERA.}

"Molluscous animals enveloped in a shell composed of carbonate of lime, forming two valves, connected by a joint, and applied the one to the right, the other to the left side; mantle two-leaved, more or less open ventrally, generally with two orifices behind; gills four-leaved, no head, mouth placed at the angle of the gills, furnished with lips and palps, sexes distinct; young undergoing a metamorphosis."

"The great majority of Molluses which inhabit bivalve shells constitute a very numerous and extensive class, distinguished by certain characters possessed by them in common. Encased in dense and massive coverings of such construction as to preclude the possibility of their maintaining more than a very imperfect intercourse with the external world, and deprived even of the means of communication with each other, we might naturally expect their organization to correspond in its general feebleness with the circumscribed means of enjoyment and limited capabilities of locomotion allotted to them. Numerous species, indeed, are from the period of their birth firmly fixed to the rock which gives them support, by a calcareous exudation that cements their shells to its surface, as is familiarly exemplified in the case of the common Oyster; or else, as the Muscles anchor themselves securely and immovably by unyielding cables of their own construction. The Scallop, unattached but scarcely better adapted for changing its position, rudely flaps together the valves of its expanded shell, and thus by repeated jerks, succecds in effecting 
a retrogressive movement. The simple apparatus by means of which shells are constructed, is the external membranous layer that invests the body of the Molluse, the mantle, as it has been termed, and, whatever the form of the shell, it owes its origin entirely to this delicate organ. When the animal is engaged in. increasing the dimensions of its abode, the margin of the mantle is protruded, and firmly adherent all round to the circumference of the valve with which it corresponds. Thus circumstanced, it secretes calcareous matter, and deposits it in a soft state upon the extreme edge of the shell, where the secretion hardens and becomes converted into a layer of solid testaceous substance. At intervals this process is repeated, and every newly-formed layer enlarges the diameter of the valve. The concentrix strata thus deposited remain distinguishable externally, and thus the lines of growth marking the progressive increase of size may easily be traced.

"It appears that at certain times the deposition of calcareous substance from the fringed circumference of the mantle is much more abundant than at others : in this case ridges are formed at distinct intervals ; or, if the border of the mantle at such periods shoots out beyond its usual position, broad plates of shell, or spines of different lengths, are secreted, which, remaining permanent, indicate, by the interspaces separating successively deposited growths of this description, the periodical stimulus to increased action that caused their formation.

"Whatever thickness this shell may subsequently attain, the external surface is thus exclusively composed of layers deposited in succession by the margin of the mantle; and, seeing that this is the ease, nothing is more easy than to understand how the colors seen upon the exterior of the shell are deposited, and assume that definite arrangement characteristic of the species. The border of the mantle contains in its substance colored spots; these when minutely examined, are found to be of a glandular character, and to owe their peculiar colors to a pigment secreted by themselves; the pigment so furnished, being therefore mixed up with the calcareous matter at the time of its deposition, colored lines are formed upon the exterior of the shell wherever these glandular organs exist. If the deposition of color from the 
glands be kept up without remission during the enlargement of the shell, the lines upon its surface are continuous and unbroken; but if the pigment be furnished only at intervals, spots or colored patches of regular form, and gradually increasing in size with the growth of the mantle, recur in a longitudinal series wherever the paint-secreting glands are met with.

"The organs of hearing consist of a pair of transparent capsules filled with a clear fluid. Each contains a glassy globule, which constantly maintains a very singular and rotary motion, that instantly ceases when the capsule is ruptured. These capsules are situated in the foot.

"Organs of vision are much more obvious, at least in many species, being often highly colored, very numerous, and prominently situated."

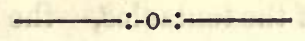

\section{GA S T E R O P O D A.}

"Molluscous animals furnished with a distinct head, and a fleshy crawling foot; either naked or protected by a shell, for the most part formed of a single piece, and generally spirally turned; mouth provided with lips, and a ribbon-like tongue, armed with rows of teeth; eyes two; tentacles two or four.Young subject to metamorphosis.

"Extensively distributed over the surface of the land, or inhabiting the waters either fresh or salt, there exists a very numerous body of Mollusca, differing widely among themselves in construction and habits, but distinguished by a peculiar locomotive apparatus common to the entire class, by means of which they are able to fix themselves to plane surfaces, and to move from place to place by a slow or gliding motion. The Slug, the Snail, the Limpet, and the Whelk, afford familiar examples of their general form and appearance.

"The upper parts in the majority of species, are covered with a fleshy cloak or mantle, the edges of which are free, in a greater or less degree, and in some cases are expanded into great lateral wings. In the Sea-hare (Aplysia), these expansions serve, by 
their waving motion, as swimming fins. The proper function of the mantle-edge is, however, the formation and increase of the shell; and hence it is always found, in shell-covered species, on that part of the body which is near the orifice. In a few species, the shell is included within the substance of the mantle. A distinct head is always present, more or less_conspicuous according to the degree in which it projects from beneath the front of the mantle. It is furnished with various organs of sense. The organs of touch are one or two pairs of contractile tentacles, placed commonly on the back of the head. In some cases these can be inverted and everted; but more generally they are solid. The hinder pair, where there are two, are often more complex in structure than the others, and are, perhaps, the seat of the sense of smell. Well-developed eyes are almost invariably present in this class. They never exceed a single pair, and are generally placed on some part of the tentacles, - the hinder ones, when there are two pairs. The most common position for these organs is at the extremity of a short fleshy column, springing from the base of the tentacle. In many species the eyes present an elaborate structure; the great Strombidoe of the tropical seas, for example, have eyes with ' a distinct pupil and a double iris, equalling, in beauty and correctness of outline, those of birds and reptiles;' and many of our native genera, as Bucsinum and Murex, are scarcely inferior, in this respect, to the Strombida.

"There is always in these animals a distinct mouth, placed at the front of the head, furnished with swollen, contractile lips, often prolonged into a cylindrical proboscis. In many species, as in Eolis, Tritonia, fc., there are two horny, sharp-edged plates, which act as jaws, playing over each other, like the blades of shears. Sometimes there is only a single jaw-plate inserted in the palate. There is, beside the jaws, a fleshy band, longer or shorter according to the genus, which performs the function of a tongue. It is sometimes grooved along its surface, and is always armed with horny teeth or spines, which are arranged in regular rows, both longitudinally and transversely. The form, number, and pattern of these teeth vary greatly, though always constant in the same species. They ' are ambercolored, glassy, and translucent; and being siliceous (they are in- 
soluble in acid), they can be used like a file for the abrasion of very hard substances. With them the Limpet rasps the stony mullipore, the Whelk bores holes in other shells, and the Cuttlefish doubtless uses its tongue in the same manner as the cat.'

"In each transverse row, there is generally a variously-toothed plate, pointing backwards, and overlapping the base of its predecessor; while on each side of this there are several lateral teeth in the form of curved spines which arch inwards. The tongue of the Limpet is longer, when extended, than the whole animal; that of the Whelk has a hundred rows of teeth, while the great Slug has one hundred and sixty rows, with one hundred and eighty teeth in each row. The stomach is sometimes armed with horny plates and teeth, as in the Sea-hare (Aplysia), which feeds on leathery Fuci.

"The shell is formed in the same manner as in the CoNcHIFERA, by the folding back of the edge of the mantle. Very many species carry on the hinder part of the body a horny or shelly plate (Operculum), which accurately closes the aperture of the shell, when the animal has withdrawn into its recesses. The form of this appendage is ordinarily that of a very flat cone, made by successive layers, each a little larger than its predecessor, or a flattened spire. The common Top-shells (Trochus,) afford good example of the spiral operculum."

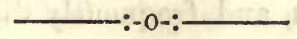

P I S E S.-F I S H E S.

"To whatever portion of the animal world we turn our attention, we find the lowest and least perfectly organized tribes to be inhabitants of the water. To dwell upon land, necessarily demands no inconsiderable share of strength and activity, limbs sufficiently strong to support the weight of the body, muscles possessed of great power and energy of action, acute and vigilant organs of sense, and, moreover, intelligence and cunning proportioned to the dangers and necessities of terrestrial existence.

"The inhabitant of the waters, on the contrary, although less highly gifted, may be fully competent to enjoy the position 
it is destined to occupy. Being constantly buoyed up on all sides by a dense element, it is easily supported at any required altitude without much muscular effort; but feeble limbs are required to guide its path through the water, and slight impulses suffice to impel it forward.

"The surface of the body of fishes, is in most instances covered by numerous scales, which vary considerably in size and substance in different species. The arrangement of these scales exhibits considerable uniformity. Each scale is attached to the fish by its anterior edge; and the manner in which the scales overlap each other in different genera, is variable, and gives an appearance of form to each scale which in reality it does not possess. By maceration in water, scales exhibit a series of laminæ, the smallest in size having been first produced: they resemble a cone, the apex of which is outward, the smallest being in the centre; hence the appearance of numerous concentric lines all of the same shape, which mark the growth.

"The fins are important, not only as organs of motion, but as affording by their structure, position, and number, materials for distinguishing orders, families, and genera. The membranes of the fins are thin, and more or less transparent, supported by slender elongated processes of bone, some of which consist of a single piece, which is pointed at the end; such fin rays are called spinous rays. Others are formed of numerous portions of bone united by articulations, and frequently divided at the end into several filaments; these, from their pliant nature, are called soft or flexible rays, and two leading divisions in systematic arrangement are founded on this difference in structure. The number of fin rays in each fin of different examples of the same species, is not always exactly alike. The names given to the different fins are derived from the part of the body to which they are attached.

"The use of the operculum or gill covers, is to close the aperture behind the gills. The blood in fishes, while passing through the gills or branchiæ, receives the influence of oxygen from the water which enters by the mouth and goes out by this aperture. In the fishes included in the first three orders, the gills are so formed, and so freely suspended, that the water bathes in its passage, every part of their surface. 
"The branchix, or gills, in fishes possess complex powers, and are capable of receiving the influence of oxygen, not only from that portion of the atmospheric air which is mixed with the water, but also directly from the atmosphere itself.

"The eyes in fishes are observed to occupy very different positions in different species. In some they are placed high up, near the top of the head, but more frequently on the flattened side of the head, but always so situated as to best suit the exigencies of the particular fish.

"The sense of hearing has by some been denied to fishes, perhaps because they exhibit no external sign of ears, but the Chinese, who breed large quantities of the well known Gold-fish, call them with a whistle to receive their food. Sir Joseph Banks used to collect his fish by sounding a bell; and Carew, the historian of Cornwall, brought his Grey Mullet together to be fed, by making a noise with two sticks.

"But from the rigid nature of the scaly covering of the generality of fishes, it is probable they possess but little external sense of touch; but they are not wholly unprovided with organs which, in the selection of their food, are of essential service. The lips in many species are soft and pulpy; the mouths of others are provided with barbules or cirri, largely supplied with nerves, which are doubtless to them, delicate organs of touch, by which they obtain cognizance of the qualities of those substances with which they come in contact. The Gurnards may be said to be provided with elongated, flexible, delicate fingers, to compensate for their bony lips. It is a rule, almost without exception that I am aware of, that those fishes provided with barbules or cirri about the mouth, obtain their food near the ground; and these feelers, as they are popularly called, appear to be a valuable compensation to those species, which, restricted by instinctive habits to feeding near the bottom of water that is often both turbid and deep, must experience more or less imperfect vision there from the deficiency of light. The olfactory nerves in fishes are of a very large size, and their sense of smell may be presumed to be acute, from the selection they are known to make in their search after food; and the advantage said to be gained by 
the various scented oils with which some anglers impregnate their baits.

"The form of the teeth in fishes is various; in general it represents that of an elongated cone, slightly curved inwards to assist in holding a prey which is frequently alive. Sometimes the form is that of a short and rounded tubercle, adapted for crushing; in some fishes the teeth are so small and numerous, as to have the appearance of the hairs of a brush; while in others they are thin and flat like the incisor teeth in the human subject. Some fishes that are without teeth in the mouth, have them in the throat, this is particularly the case in the Carp, and the allied species of the family of the Cyprinidoe generally. Fishes have cold blood; that is to say, the blood does not, in general, rise appreciably above the temperature of the element in which they swim. It is invariably red. The heart consists of one auricle and one ventricle, which receives the blood from the veins, and sends it to the gills for renewal by the absorption of oxygen; whence it is circulated through the body in arteries. Both the arteries and veins are perfectly closed vessels. In many fishes there is a large bladder situated within the body between the spine and the bowels; it assumes various forms, and is always filled with air, which, in marine fishes, is principally composed of oxygen. It is supposed to be connected with the buoyancy of the animal, and hence is often called the swimming bladder; but there are structural reasons for considering it to be the first rudimentary form of an air-breathing lung.

"The air bladder does not occur in all fishes; some fishes, and those particularly that live near the bottom of the water are without any. 'The swimming bladder of fishes,' says Dr. Roget in his excellent Bridgewater Treatise, 'is regarded by many of the German naturalists as having some relations with the respiratory function, and as being the rudiment of the pulmonary cavity of land animals; the passage of connection with the osophagus being conceived to represent the trachea.' Hervey long ago observed 'that the air in birds passed into cells beyond the substance of the lungs; thus showing a resemblance to the cellular lungs in reptiles, and the air-bladder in fishes.' M. Agassiz, in dissecting a species of Lepisosteus, a fresh water 
fish of the waters of America, found the air-bladder composed of several cells, with a canal proceeding upwards into the pharynx, and ending in an elongated slit, with everted edges, resembling a glottis or tracheal aperture. However obvious may be these relations of structure, it is still difficult to believe that there can be any analogy in function, when it is recollected that one-fourth of the fishes known are entirely without air-bladders, and that two-thirds of the other three-fourths have neither canal nor aperture for external communication, but that all are provided with gills. The search for these relations of structure in animals of different classes, is among the most interesting of the investigations of the comparative anatomist."

\section{THE HIPPOCAMPUS.}

" Mr. Lukis, who had in 1835 two of these animals, which had been living twelve days in a glass vessel, at the time of writing said, 'an appearance of search for a resting place induced me to consult their wishes by placing straws and sea-weed in the vessel; the desired effect was obtained, and has afforded me much to reflect upon in their habits. They now exhibit many of their peculiarities, and few subjects of the deep have displayed in prison more sport or more intelligence.'

"When swimming about they maintain a vertical position; but the tail is ready to grasp whatever meets it in the water; quickly entwines in any direction around the weeds, and when fixed, the animal intently watches the surrounding objects, and darts at its prey with great dexterity.

"When both approach each other, they often twist their tails together, and struggle to separate or attach themselves to the weeds; this is done by the under part of their cheeks or chin, which is also used for raising the body, when a new spot is wanted for the tail to entwine afresh." 


\section{IN D EX.}

PAGE.

Algx.-(Sea Weeds.) - . $\quad$ - 1

Poriphora.-(Sponge.) • • . 4

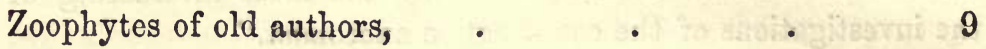

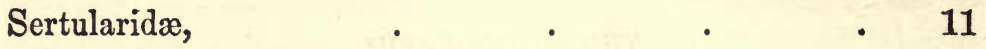

Anthozoa Asteroida, _ . $\quad$ - $\quad 15$

Gorgonidæ, $\quad$ - $\quad$ - $\quad \ldots \quad$ - 15

Pennatulidx, $\quad$ - $\quad$. 16

Actiniadæ.-(Sea Anemones.) . _ . . 17

Acalephæ, $\quad$ - $\quad$ - $\quad$ - $\quad 22$

Echinodermata.-(Asteroidea.) • • • 24

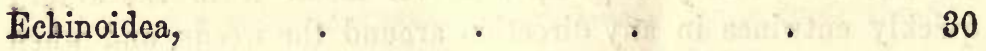

Holothuroidea, $\quad$ - $\quad$ - $\quad$ - 36

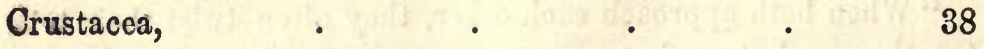

Cirrhopoda, .

Conchifera, $\quad$ - $\quad$. $\quad$. 43

Gasteropoda, • ‘ $\quad$ • $\quad$. $\quad$. $\quad$. 45

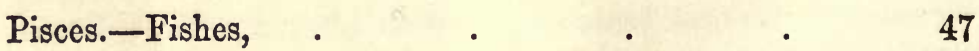

The Hippocampus, ․ $\quad$ - $\quad$. $\quad$ - 51 


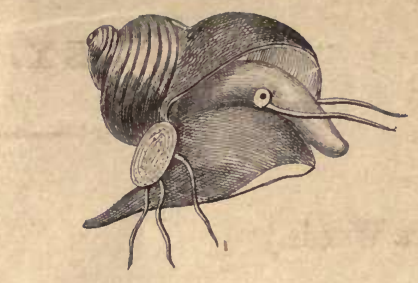

Trochus araucanus.
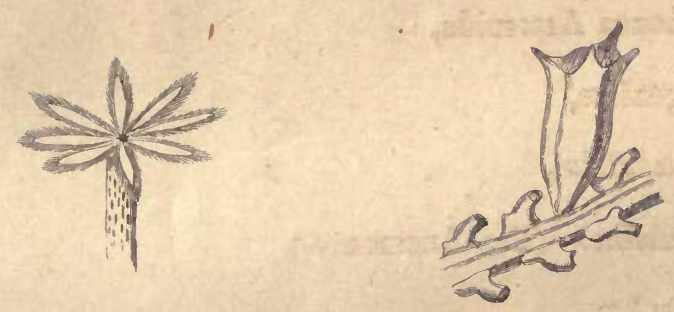

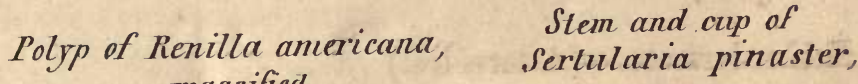 magnified. magnified.

$$
\text { Murex patagonicus }
$$









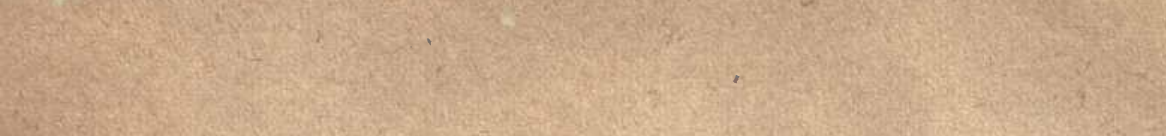

S

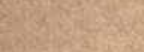

Xetion

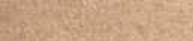

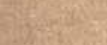

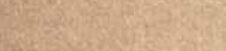

1050

aryos

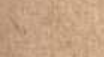

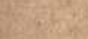

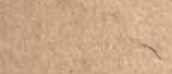

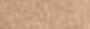

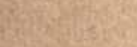

vatphesing

2 










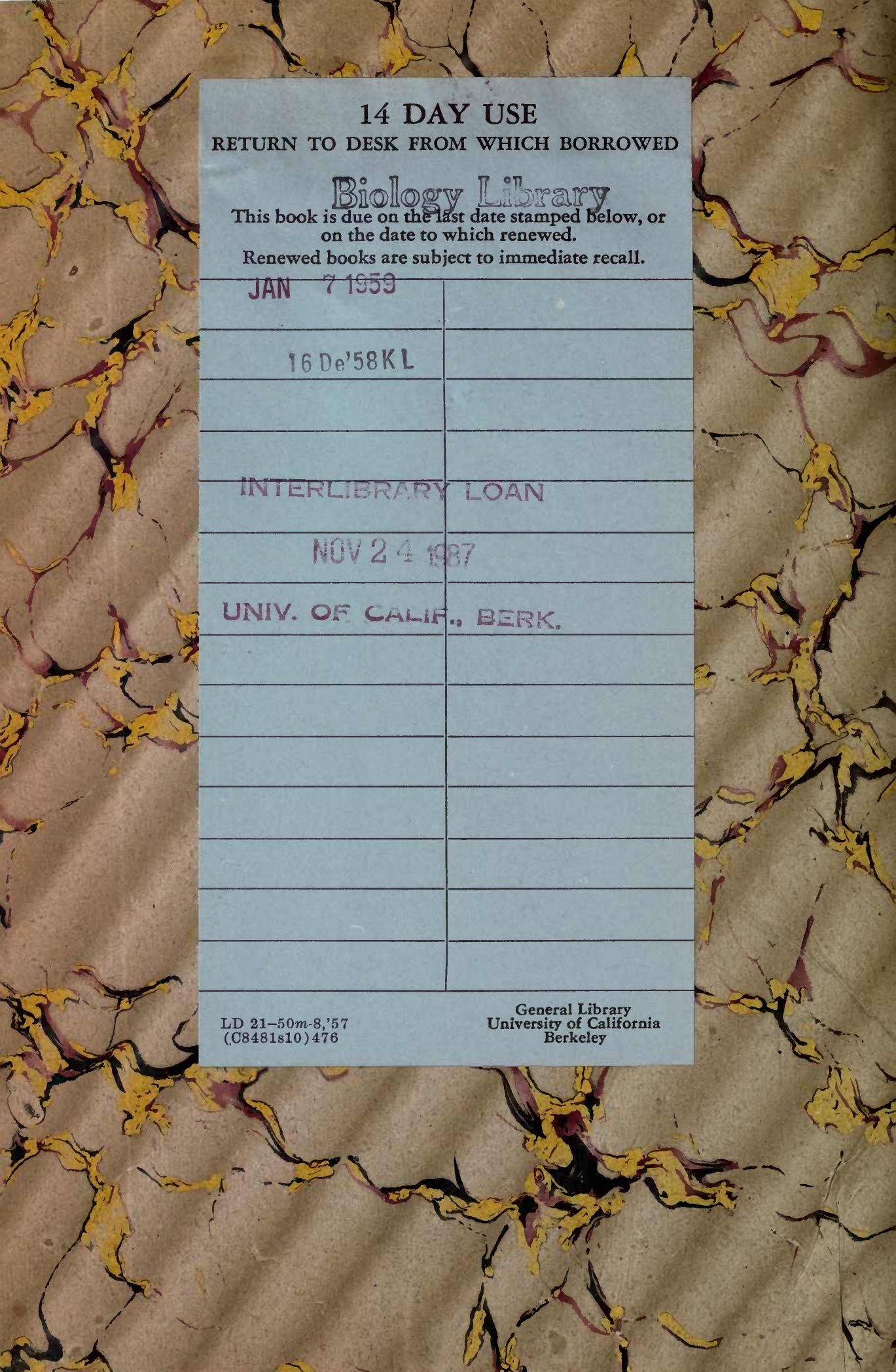




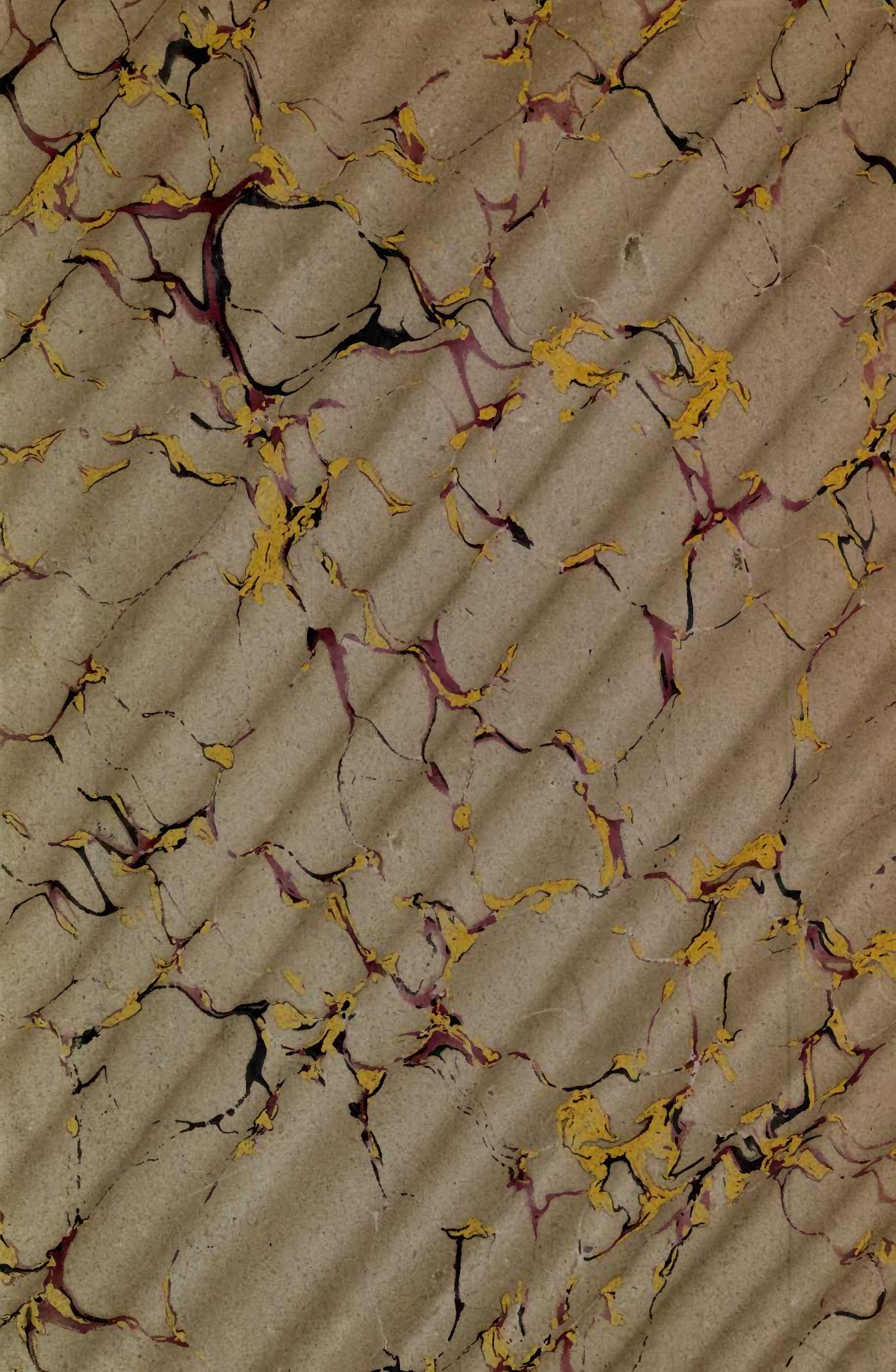

\section{9}


